\title{
$r-g<0:$ Can We Sleep More Soundly?
}

\author{
Paolo Mauro ${ }^{1}$ Jing Zhou ${ }^{1}$
}

Published online: 13 January 2021

๑ International Monetary Fund 2021

\begin{abstract}
Contrary to the traditional assumption of interest rates on government debt exceeding economic growth, negative interest-growth differentials became prevalent after the global financial crisis and before the COVID-19 pandemic. Should negative differentials be grounds for sleeping more soundly, despite high government debts? We analyze interest-growth differentials using data on average effective borrowing costs for 55 countries over up to 200 years. Negative differentials prevail for both advanced and emerging economies. Even so, several default episodes have followed periods of negative differentials, and differentials are no higher prior to defaults than in normal times. Marginal (rather than average) government borrowing costs often rise sharply, but just preceding default. Based on these results, our answer is: not really.
\end{abstract}

JEL Classification E43 $\cdot \mathrm{E} 62 \cdot \mathrm{H} 63$

\section{Introduction}

Standard economic models assume that the interest rate is higher than the growth rate of the economy. In applications to countries' public finances, if economic growth exceeds the cost of government borrowing, the government can just roll over its debt, and the debt-to-GDP ratio will decline without the need to increase taxes. Economists have recently started rethinking whether the assumption of a positive interest-growth differential is sufficiently grounded in empirical experience and what the implications of relaxing such assumptions would be. In his 2019 American Economic Association presidential address, Olivier Blanchard reminded us that the interest-growth differential for government debt has often been negative in the USA. Moreover, differentials were negative, on average, in a majority of advanced

Paolo Mauro

pmauro@imf.org

Jing Zhou

jzhou@imf.org

1 Fiscal Affairs Department, IMF, Washington, USA 
economies following the Global Financial Crisis (GFC) that began in 2008 and prior to the economic collapse induced by COVID-19 in mid-2020. Many analysts expect that low interest rates will prevail for a long time - at least in those large advanced economies considered to be a safe haven-even after the pandemic abates and economic growth returns to a healthy pace [see, for example, International Monetary Fund (2020)]. Policymakers will need to weigh such negative differentials against the background of higher public debts than prior to the GFC. ${ }^{1}$ In this paper, we provide evidence on the prevalence of negative differentials over the past two centuries in 55 advanced and emerging economies. We also show that differentials in countryyears preceding defaults on public debts are no higher than usual, suggesting that interest-growth differentials have no predictive power for government defaults-at least not until it is too late for policies to take corrective actions.

The prevalence of high debt levels and low interest-growth differentials suggests several interrelated questions. First, were the low interest-growth differentials experienced between the GFC and the COVID-19 pandemic unique from a historical perspective? Second, are there any prominent drivers of changes in such differentials? Third, what is the empirical association between interest-growth differentials and sovereign defaults? Can low interest-growth differentials be viewed as strengthening debt sustainability?

In this paper, we address these questions empirically. We begin by assembling data on interest-growth differentials. In previous studies, the best sources of interestgrowth differentials are based on marginal borrowing rates (secondary market yields on long-term government bonds) from Jordà et al. (2017) for advanced economies data or author-collected bond-specific data such as Reinhart and Sbrancia (2015). We construct a larger dataset that contains the public finances, average government borrowing costs, and economic growth for 55 advanced and emerging countries over up to 200 years, drawing primarily on Mauro et al. (2015) who had used similar data to analyze the determinants of countries' primary fiscal surpluses. These data refer to the average effective cost of servicing debt (the ratio of the interest bill to government debt), which is the appropriate measure for standard debt dynamics accounting equations. ${ }^{2}$ For a somewhat smaller sample, we also use marginal borrowing rates. These react faster to changes in market perceptions, but are an imperfect proxy for future effective interest rates (as further discussed below). Whenever possible, we

\footnotetext{
1 Public debts have increased substantially around the world since the outset of the GFC. In June 2020, the IMF's World Economic Outlook projected that at end-2020, debt-to-GDP ratios would exceed 130 percent for the advanced economies (the highest since WWII), 60 percent for emerging markets (a level not seen since the early 1980s), and almost 50 percent for the low-income countries (compared with 30 percent pre-GFC). Rising indebtedness has engendered concerns regarding debt sustainability. Primary deficits are projected to rise in the advanced economies as a result of aging populations and in emerging and low-income countries as a result of the need to invest in human and physical capital. Policymakers need to assess whether low or negative interest-growth differentials will be enough to offset such fiscal pressures and ensuing risks.

2 Based on the government flow budget constraint $d_{t}-d_{t-1}=\frac{1+r_{t}}{1+g_{t}} \cdot d_{t-1}+p d_{t} \approx\left(r_{t}-g_{t}\right) d_{t-1}+p d_{t}$, where $d$ is the public debt as share of GDP, $p d$ is the primary deficit as share of GDP, $g$ is the nominal growth rate, and $r$ is the average effective interest rate on the public debt. For more details, see, for instance, Escolano (2010).
} 
take account of the role of exchange rate depreciation in the de facto cost of borrowing in foreign currency, although this portion of the analysis is constrained by the limited availability of data on the share of foreign currency public debt in total public debt.

We document five empirical regularities. First, negative interest-growth differentials occur for prolonged periods in history in both advanced and emerging economies. Second, the often-held view that differentials are more likely negative in emerging than in advanced economies stems largely from the period between the first oil shock of 1973-1974 and the mid-1990s: During that time, the advanced economies liberalized their capital markets and sought to curb inflation by allowing interest rates to rise faster than inflation, whereas the emerging economies continued to use financial repression against the background of high inflation. Prior to the 1980s, the advanced economies engaged in financial repression too, and by the mid-1990s, many emerging economies had also liberalized their financial markets. Third, the fiscal stance is somewhat more expansionary, on average, when interestgrowth differentials are low: When differentials decline, the primary fiscal deficit increases, but not nearly enough to fully compensate. Fourth, interest-growth differentials computed using the average effective interest rate on government borrowing are essentially useless to predict government defaults, although there is some evidence of a decline in economic growth in the run-up to defaults and growth is significantly below the norm the year prior to default. Fifth, marginal interest rates (on new government borrowing or on the secondary market) often rise sharply and abruptly but only a few months ahead of defaults.

To sum up, should low interest-growth differentials be a cause for sounder sleep? For those who lose sleep over possible debt crises, the answer is: perhaps a little, but not really. History teaches us that many crises have occurred after years of low differentials, and that market expectations can turn quickly and abruptly, shutting countries out of financial markets in a matter of a few months.

\subsection{Related Literature}

This paper intends to contribute to three strands of the literature. First, several studies have analyzed interest-growth differentials for either limited country samples or short sample periods-for instance, Ball et al. (1995) and Mehrotra and Sergeyev (2020) on the USA, Mehrotra (2019), Jordà et al. (2019), and Schmelzing (2019) on advanced economies, Escolano et al. (2017) on advanced and emerging economies, and Turner and Spinelli (2011) on OECD economies since the 1980s. ${ }^{3}$ Some of these studies (Turner and Spinelli 2011; Escolano et al. 2017; Kozlowski et al. 2019; Rachel and Summers 2019) investigate the reasons for negative interest-growth differentials or low interest rates on "safe" government bonds-such as financial repression, global saving glut, secular stagnation, and significant tail risks, whereas others

\footnotetext{
${ }^{3}$ Our paper focuses on the interest rate for government borrowing, not on the (usually higher) return on capital, which relates to a different literature on dynamic efficiency [e.g., Abel et al. (1989) and Geerolf (2018)] or prospects for future inequality [e.g., Piketty (2014)].
} 
take negative interest-growth differentials as given and analyze their implications for debt sustainability and fiscal policies (Barrett 2018; Blanchard 2019; Mehrotra 2019; Mehrotra and Sergeyev 2020). This paper extends the empirical analysis by drawing on a rich historical cross-country dataset, giving us a broader perspective on some of the factors underlying variation in interest-growth differentials.

Second, this paper is related to the studies on financial repression and debt sustainability, which gauge the effects of financial repression on debt servicing costs (Giovannini and De Melo 1991; Reinhart and Sbrancia 2015; Reinhart et al. 2011) or establish the optimal financial repression given sovereign default risks (Chari et al. 2020). Building on these studies, our paper employs new ways to systematically date financial repression-including de jure measures of financial repression and de facto measures based on deviations from uncovered interest rate parity. Utilizing these identified country-year pairs where financial repression prevails, this paper provides better estimates of the impact of financial repression on government borrowing costs.

Third, this paper is linked to the studies on debt sustainability and sovereign defaults. The previous work has documented that marginal borrowing costs often spike in the run-up to sovereign defaults [for example, Arellano (2008), Broner et al. (2013), Abbas et al. (2019)], typically drawing on data beginning in the 1980s. Our new long time series allows us to compare the behavior of marginal and average effective rates since the late 1800 s. We find that interest-growth differentials can be negative for prolonged periods followed by sudden spikes in marginal borrowing costs that may well culminate in defaults.

The remainder of the paper is organized as follows. Section 2 describes the data and provides a refresher on the relative merits of tracking the effective and marginal cost of borrowing in long-run analysis of government debt solvency and the likelihood of default. Section 3 reports stylized facts on the prevalence of negative interest-growth differentials in long-run historical data, notes that the divergence between advanced and emerging economies is largely confined to 1975-1995, and shows that financial repression and inflation account for the divergence. Section 4 explores the potential association between sovereign defaults and the differences between effective (or marginal) interest rates and economic growth. Section 5 concludes.

\section{Data}

This paper draws on a dataset consisting of fiscal variables for 55 countries over up to 200 years (Mauro et al. (2015), updated to 2018) - to our knowledge, the most comprehensive dataset currently available for both fiscal flows (including the interest bill) and stocks. We augment these data with information on money market rates, sovereign defaults, and financial market reforms. Full data sources are reported in "Appendix 1." Our final dataset consists of a cross-country panel over long time periods for interest payments, public debt stocks, gross domestic products, external public debts, fiscal balances, money market rates, exchange rates, sovereign default 
indicators, and policy-based variables on the level of liberalization in financial markets.

The key variable - the interest-growth differential-is constructed as the difference between the effective interest rate and the nominal growth rate. The effective interest rate contains two parts: one is the ratio between the interest bill and the average of the current and previous years' public debt stocks, and the other is the depreciation adjustment. ${ }^{4}$ For countries that issue public debt in foreign currencies, exchange rate depreciation is an important factor driving changes in public debt, as emphasized by studies on "original sin" [such as Eichengreen et al. (2010)]. We include the depreciation adjustment whenever the necessary data on foreign currency public debt are available-for emerging economies, this means from 1970s as the earliest. For the final sample, we exclude domestic and external sovereign default years (where the intertemporal government budget constraint does not apply), hyperinflation (greater than $100 \%$ ), and extreme exchange rate collapse (top 1 percentile depreciation of the whole sample).

\subsection{Effective Versus Marginal Interest Rates-A Refresher}

Our focus in this paper is the effective interest rate on a country's government debtdefined, as customary, as the flow of interest payments during the year divided by the stock of debt [see, for example, Escolano (2010)]..$^{5}$ As such, loosely speaking, the effective interest rate is a weighted average of the interest rates on each bond issued or loan contracted by the country that remains outstanding. By definition, it is the best representation of the fiscal cost of a country's debt and the most relevant indicator of the cost of borrowing from the perspective of determining a country's solvency. As noted in Introduction, the effective interest rate drives the motion of the debt ratio through the standard equation [see, for example, Best et al. (2019)]. Our data refer to the ex post effective interest rate- the relevant measure to explain what happened to the debt ratio.

In some exercises and robustness tests, we also consider the secondary market yield on 10-year government bonds. Following common usage, we will occasionally refer to this as the "marginal" interest rate, although this is a bit of a misnomer, because strictly speaking there is no single marginal interest rate: The interest rate on an extra unit of debt issued by the government depends on the specific features, such as maturity and currency denomination, of such issuance.

Studies that use a single interest rate, and especially those studies that focus on defaults, usually analyze the secondary market interest rate on long-term government bonds (typically 10-year government bonds), because long-term rates vary

\footnotetext{
4 The differential is equal to $r_{t}-g_{t}+\alpha_{t-1} \cdot s_{t} . r$ is the effective interest rate calculated as the rate of interest payment to total debt, $g$ is the growth rate, $s$ is the depreciation rate (against the US dollar), and $\alpha$ is the share of external debt in total public debt. The last multiplication term captures the increase in debt-when expressed in domestic currency-if there is a depreciation.

5 More precisely, as the denominator in the interest bill-to-debt ratio, we use the average of the end-year debt stocks for the previous and current calendar years.
} 
more significantly in response to changes in default risk or macroeconomic developments. In contrast, short-term rates tend to be more stable and respond more closely to changes in the stance of monetary policy. Researchers also choose the currency denomination of interest depending on the relative importance of domestic versus foreign currency in a country's issuance and the liquidity of the market. For example, researchers who are mainly interested in advanced economies [such as Jordà et al. (2017, 2019)] tend to focus on domestic currency bonds, whereas researchers analyzing emerging economies [such as Mauro et al. (2002)] use bonds denominated in foreign currency (typically British pounds pre-WWI and US dollars in the postBrady deal era).

For our purpose of tracing the impact of the cost of borrowing on government solvency, using the effective interest rate rather than a single interest rate has several advantages, both conceptual and practical. On the conceptual side, countries borrow through a variety of instruments whose returns may differ systematically: For example, long-term interest rates are usually higher than short-term interest rates. Measuring the cost of borrowing only through long-term rates would thus overestimate the average effective cost of borrowing (as we show in some exercises below). Moreover, the maturity and currency composition of a country's borrowing change over time-especially when considering a sample period spanning two centuries. And the short-term versus long-term mix as well as the currency mix in a country's marginal borrowing often changes abruptly in the most interesting times-when investor sentiment deteriorates and a country's cost of borrowing rises, as documented by Detragiache and Spilimbergo (2001) and Jeanne and Guscina (2006). One of the most notable examples is Mexico in the run-up to its 1994 crisis, when it issued sizable amounts of short-term Tesobonos with a guaranteed repayment in US dollars.

Moreover, from the practical standpoint of data availability, using effective interest rates allows us to cover a much broader sample of countries. Every year, countries appropriately report how much they spend on interest in their budgets. We exploit this rich dataset which covers not only the advanced economies-where defaults in any case have been rare events - but also many emerging and developing economies where the topic of default has historically been of more central interest. In contrast, using a single interest rate for emerging economies for a century long time series would not be feasible or appropriate. Emerging economies borrowed heavily on the London market pre-WWI, then got shut out of global markets, returned to international borrowing through syndicated bank loans in the 1970s, and relied on sovereign bonds after the Brady deals of the late 1980s and early 1990s [Obstfeld and Taylor (2005)]. Meanwhile, the relative importance of domestic borrowing changed massively as a result. It might be argued that marginal rates are superior to effective interest rates because they are leading indicators of future developments in the effective rates. However, in practice marginal rates are a rather imperfect proxy for future effective rates, for several reasons. First, the effective interest rate may be changing (with no uncertainty) due to mechanical effects: Consider the common case of an economy that has experienced a decline in inflation during the previous decade or so. The oldest outstanding bonds that will come to maturity next year bear a higher interest rate than those that were issued more recently and will thus continue to be 
serviced. This mechanical effect implies a tendency for the effective interest rate to decline next year. If hypothetically the country is facing an increase in the marginal rate (a higher borrowing cost on new issuance), the effective interest rate may well continue declining if the mechanical effect prevails over the increase in the marginal rate.

Second, the marginal rate has both the advantage and the disadvantage of reacting quickly to changes in investor sentiment. As we document toward the end of this paper, investors sometimes lose confidence in a country's ability to repay and abruptly ask for much higher interest rates on new borrowing (if any is extended). In some cases, the country is no longer able to refinance itself, and a so-called rollover crisis results in a default. In several instances, however, a spike in the marginal rate is reversed after a few months, no default occurs, and the country's effective interest rate rises by a small amount. Prominent examples of such reversals in investor sentiment include Chile and several other emerging markets during "contagion" episodes experienced during the Mexican (1994-1995), Asian (1997-1998), Russian (1998), and (for fewer countries) Argentine (2002) and Lehman (2008) crises. ${ }^{6}$ In a more country-specific episode, Brazil's sovereign bond spreads surpassed 2000 basis points in the summer and fall of 2002, but eventually fell below 500 basis points by late 2003 and declined further in later years.

On the whole, as we show in the empirical exercises, the marginal rate is indeed a better leading indicator of rollover crises and captures well changes in investor sentiment, but does so only a few months in advance of default. In contrast, the effective rate moves more slowly and as such is a poor leading indicator of default; on the other hand, it does not react to changes in sentiment that are later reversed and end up being simply noise.

\section{Interest-Growth Differentials: Empirical Regularities}

We begin by exploring the stylized facts of interest-growth differentials, considering the evolution of interest-growth differentials in different time periods and country groups.

\subsection{The Prevalence of Negative Interest-Growth Differentials in History}

On average, interest-growth differentials are negative for both advanced and emerging economies. ${ }^{7}$ Using the average effective interest rate data, the differentials are

\footnotetext{
${ }^{6}$ Based on the available data on EMBIG sovereign bond spreads for the periods including those episodes, there are more than 30 instances in which a country's spreads rose above 1,000 basis points. Of those, seven eventually resulted in default; in the remainder, the spreads eventually declined, and no default occurred. Details can be found in Cottarelli et al. (2010).

7 The classification of advanced and emerging economies is based on the present day definition from the International Monetary Fund's World Economic Outlook. We use these country groups for illustration as customary, fully recognizing that the distinction between advanced and emerging economies is not static throughout: For instance, Australia and Canada were clearly emerging economies in the pre-WWI period.
} 
Table 1 Summary statistics: interest-growth differentials by time periods

\begin{tabular}{|c|c|c|c|c|c|c|c|c|c|c|}
\hline & \multicolumn{2}{|c|}{ Full sample } & \multicolumn{2}{|c|}{ Pre-WWII } & \multicolumn{2}{|c|}{ Post-WWII } & \multicolumn{2}{|c|}{ Post-1980 } & \multicolumn{2}{|c|}{ Post-GFC } \\
\hline & $\mathrm{AE}$ & $\mathrm{EM}$ & $\mathrm{AE}$ & EM & $\mathrm{AE}$ & EM & $\mathrm{AE}$ & EM & $\mathrm{AE}$ & EM \\
\hline \multicolumn{11}{|c|}{ Based on average effective interest rates } \\
\hline Mean & -2.4 & -6.6 & 0.3 & 2.0 & -3.1 & -7.6 & 0.1 & -5.5 & 0.5 & -2.9 \\
\hline Median & -1.3 & -4.8 & 0.8 & 2.4 & -1.7 & -5.3 & 0.5 & -3.9 & -0.0 & -2.2 \\
\hline Standard Deviation & 9.1 & 14.3 & 8.5 & 10.4 & 8.0 & 14.4 & 6.2 & 12.3 & 3.8 & 7.4 \\
\hline $\mathrm{N}$ & 2789 & 1468 & 1009 & 146 & 1579 & 1273 & 906 & 867 & 239 & 306 \\
\hline \multicolumn{11}{|c|}{ Based on long-term secondary market interest rates } \\
\hline Mean & -1.0 & -0.6 & 1.1 & - & -1.2 & -0.6 & 0.9 & -0.6 & 0.2 & 0.4 \\
\hline Median & -0.6 & -0.1 & 1.3 & - & -1.0 & -0.1 & 0.7 & -0.1 & -1.0 & 0.2 \\
\hline Standard Deviation & 7.9 & 14.8 & 8.4 & - & 5.2 & 14.8 & 3.9 & 14.8 & 5.0 & 12.1 \\
\hline $\mathrm{N}$ & 2584 & 481 & 970 & - & 1413 & 481 & 816 & 481 & 226 & 246 \\
\hline
\end{tabular}

This table presents the summary statistics of interest-growth differentials by time periods. The differentials in the top panel are based on average effective interest rates, and the differentials in the bottom panel are based on long-term secondary market interest rates. The AE and EM refer to advanced economies and emerging economies, respectively. Pre-WWII period is from 1800 to 1938, excluding WWI observations. Post-WWII period is from 1950 to 2018. Post-GFC refers to 2009-2018

approximately negative 2.5 percentage points for advanced economies on average and negative 6.5 percentage points for emerging economies (Table 1). Across time, differentials are more negative post-WWII than pre-WWII and more negative pre-GFC than post-GFC. Across countries, emerging economies show lower differentials than advanced economies, although as will be shown below this difference stems largely from 1975 to 1995 . The differentials are also negative-for both means and medians - using long-term interest rates ("marginal" rates, for short) based on secondary market yields ${ }^{8}$ for the somewhat smaller sample for which they are available. Not surprisingly, the differentials using the marginal rates are less negative than using average effective interest rates, because-as is well known-longterm interest rates tend to be higher than short-term interest rates.

Considering the descriptive statistics in greater detail using differentials based on average effective interest rates, the medians for both country groups are less negative than the means (Fig. 1), indicating that tail events of very negative differentials are more common than highly positive ones. For the low and high ends of the distribution, the most negative differentials are associated with high growth (postwar, for instance), and the most positive ones come from large depreciation.

Negative interest-growth differentials have occurred more frequently than not over the past two centuries for both advanced and emerging economies, though the frequency of negative interest-growth differentials varies across countries. Figure 2 presents the share of years in which the differential was negative, for each of the

\footnotetext{
${ }^{8}$ Following the literature such as Jordà et al. (2019) and Mauro et al. (2002), we use 10-year domestic bond yields for advanced economies and 10-year foreign currency-denominated bond yields (the sum of EMBI spreads and 10-year US Treasury bill yield) for emerging economies.
} 


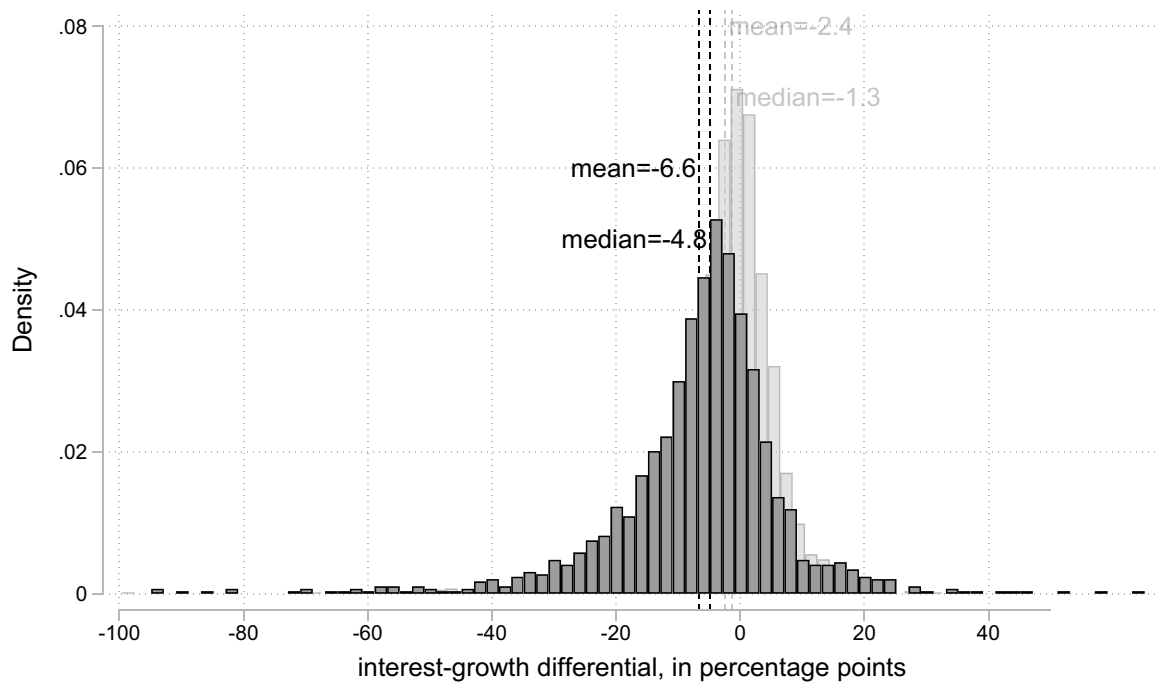

$\square$ AE $\square$ EM

Fig. 1 Distribution of interest-growth differentials. Note This chart plots the whole distribution of interest-growth differentials for advanced economies and emerging economies for all the observations (2789 for advanced economies and 1468 for emerging economies). The vertical lines indicate means and medians, as denoted in the chart
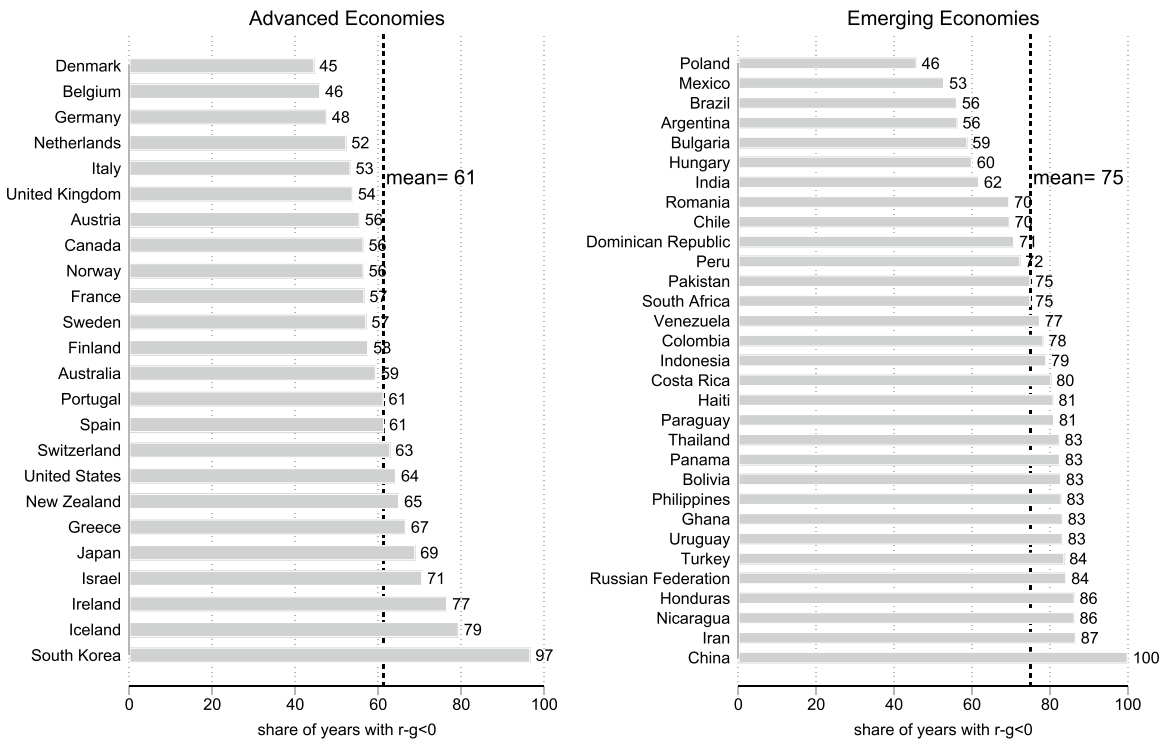

Fig. 2 Share of years (in percent) with negative interest-growth differentials, by country. Note This chart plots the share of years with negative interest-growth differentials for each country. The sample period with available data depends on the country. The full sample is from 1800 to 2018 for advanced economies and 1865 to 2018 for emerging economies. The dashed vertical line indicates the mean share across countries in each group 
Table 2 Correlations between interest rate, growth, and interest-growth differential

\begin{tabular}{|c|c|c|c|c|c|c|}
\hline & \multicolumn{3}{|l|}{$\mathrm{AE}$} & \multicolumn{3}{|l|}{ EM } \\
\hline & \multicolumn{2}{|l|}{ Pooling } & \multirow{2}{*}{$\begin{array}{l}\text { Average } \\
\text { Correlation }\end{array}$} & \multicolumn{2}{|l|}{ Pooling } & \multirow{2}{*}{$\begin{array}{l}\text { Average } \\
\text { Correlation }\end{array}$} \\
\hline & Correlation & $p$ value & & Correlation & $p$ value & \\
\hline \multicolumn{7}{|c|}{ Full sample } \\
\hline$r-g, g$ & -0.46 & 0.00 & -0.49 & -0.31 & 0.00 & -0.41 \\
\hline$r-g, r$ & 0.89 & 0.00 & 0.86 & 0.82 & 0.00 & 0.72 \\
\hline$r, g$ & -0.02 & 0.32 & -0.02 & 0.08 & 0.00 & 0.00 \\
\hline $\mathrm{N}$ & 2789 & 2789 & 2789 & 1468 & 1468 & 1468 \\
\hline \multicolumn{7}{|c|}{ Post-WWII } \\
\hline$r-g, g$ & -0.51 & 0.00 & -0.55 & -0.30 & 0.00 & -0.41 \\
\hline$r-g, r$ & 0.92 & 0.00 & 0.86 & 0.81 & 0.00 & 0.71 \\
\hline$r, g$ & -0.15 & 0.00 & -0.12 & 0.07 & 0.01 & -0.01 \\
\hline $\mathrm{N}$ & 1579 & 1579 & 1579 & 1273 & 1273 & 1273 \\
\hline
\end{tabular}

This table presents the correlations between average effective interest rate, growth, and interest-growth differential by time periods. The results for advanced economies and emerging economies are presented in the left and right panel, respectively. The second and fifth columns show the correlations by pooling all the observations, and the $p$ values are shown in the third and sixth columns. The fourth and seventh columns show the averages of within-country correlations. Post-WWII period is from 1950 to 2018

55 countries in our sample. Although negative interest-growth differentials are the norm-occurring more than half of the time for both advanced and emerging economies - the frequency of negative differentials for emerging economies is about 15 percentage points larger than for the advanced economies.

The correlation between the interest rate and the differential is higher (in absolute terms) than the correlation between the growth rate and the differential (Table 2). Both correlations are statistically significant. The correlation between the interest rate and the growth rate is close to zero and not robust. These results hold when all observations are pooled together, for subperiods, and also when considering the cross-country average of the within-country correlations (where the variables are deviations from country means). ${ }^{9}$ On the whole, movements in the differential come from both interest rates and economic growth, although more of the action is associated with the former, consistent with the results reported by Jordà et al. (2019).

\subsection{The Divergence Between Advanced and Emerging Economies (1975-1995)}

Interest-growth differentials for country groups vary considerably over time. Average differentials are strongly negative during the two world wars and in the period between WWII and the first oil shock. Indeed, advanced and emerging economy average differentials move closely with each other until around 1975 (Fig. 3). From

\footnotetext{
9 Additional country-by-country and long-horizon results are available upon request.
}

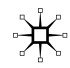



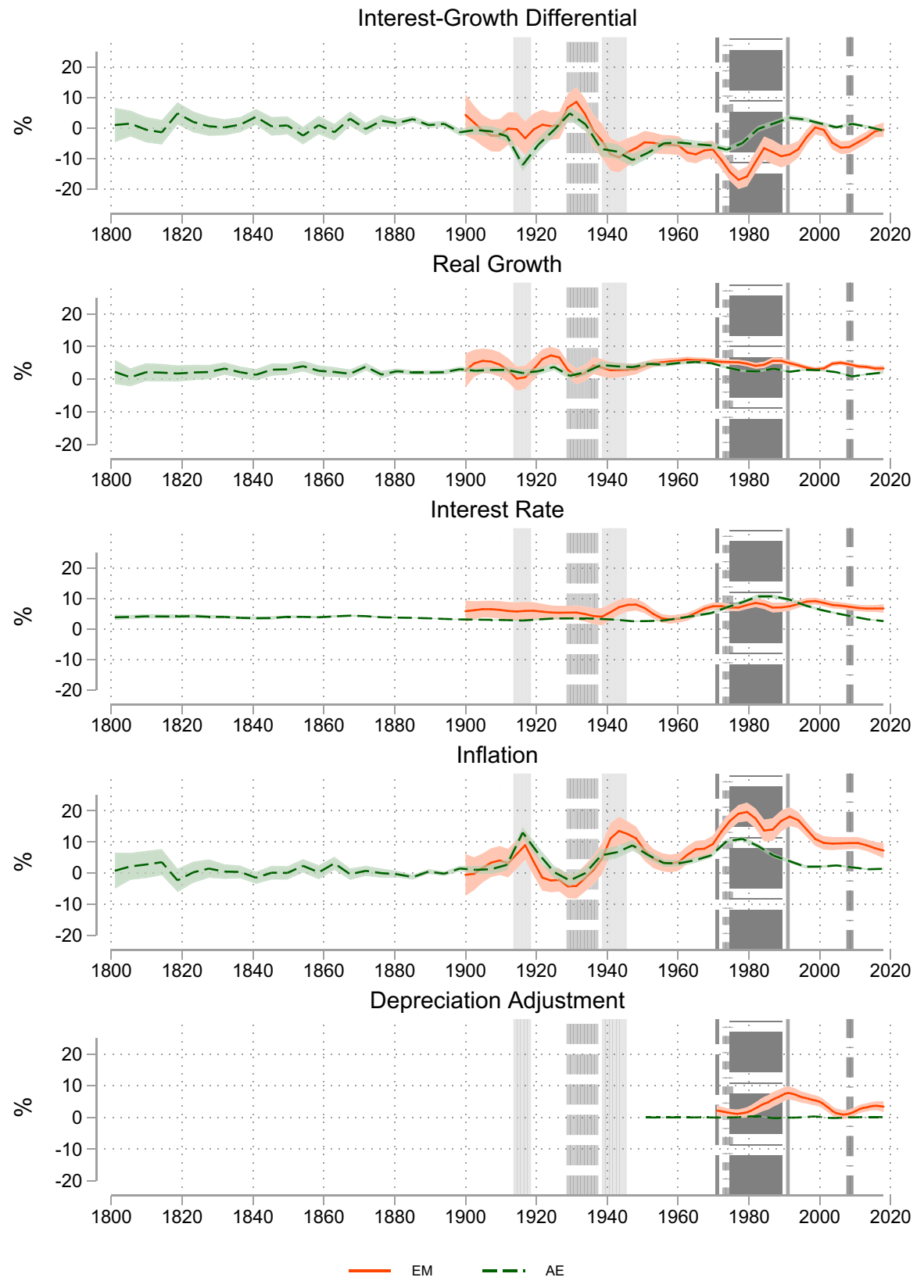

Fig. 3 Divergence between advanced and emerging economies. Note This chart plots the average of interestgrowth differential, real growth, effective interest rate, and inflation of advanced economies and emerging countries, respectively. The confidence band is calculated with normal kernel smoothing. The advanced economies include AUS, BEL, CAN, DEU, DNK, ESP, FRA, GBR, ITA, JPN, NLD, NOR, NZL, PRT, SWE, and USA, which have at least 100 observations. The emerging countries included are ARG, BRA, COL, CRI, IND, MEX, PAK, PHL, THA, VEN, and ZAF, which have at least 50 observations. From left to right, the shaders represent WWI, Great Depression, WWII, Bretton Woods breakdown, 1970s US, UK Recessions, financial liberalization, oil shock, and Great Recession 
1975 to 1995 , the differentials diverge between the two country groups, and the average gap widens to 20 percentage points at its peak. The gap narrows in the late 1990s, as emerging economies' differentials shrink, and it becomes insignificant in the late 2010s. The divergence between advanced and emerging economies emerges again around 2005. However, it is partly due to a few emerging economies reintroducing financial repression, which will be shown in the next section to be an important factor driving the divergence.

This divergence is jointly driven by the gap in inflation rates between the two country groups and the different responses of their nominal interest rates to inflation. As an accounting identity, interest-growth differentials can be decomposed into the differentials of nominal interest rates, inflation, real growth, and depreciation adjustment. Assessing each component separately, the gap across country groups is largely accounted for by differences in inflation during 1975-1995, whereas differences in interest rates, real growth, and depreciation adjustment are small (Fig. 3). In other words, nominal interest rates rose significantly less in response to inflation in the emerging economies than in the advanced economies.

\subsection{The Role of Financial Repression and Inflation in Interest-Growth Differentials}

Understanding the post-WWII episode and the divergence in differentials between advanced and emerging economies during 1975 to 1995 requires analyzing inflation as well as financial repression, which creates and maintains a captive domestic audience. In turn, this facilitates directing credit to the government (such as interest rate controls, capital controls, reserve requirements, and government ownership of banks). In this section, we focus on the 1975-1995 divergence episode because many policymakers seem to view emerging economies as more prone to negative differentials than advanced economies. Analysis of this episode helps to reconfirm that negative differentials are not the sole confine of emerging economies.

Financial repression, in combination with inflation, reduces the cost of debt in significant periods in history. In their study on 12 advanced economies, Reinhart and Sbrancia (2015) find that the savings of annual debt interest payments amounted to up to 5 percent. On a sample of 24 countries, Giovannini and De Melo (1991) estimate that the annual revenue gain from financial repression can be as large as 5 percent of GDP in several countries. This effect is also supported by a comparison of the interest-growth differentials between advanced economies and emerging economies. As shown in Fig. 3, before the early 1970s, the two country groups move along with each other, and the gap between their interest-growth differentials is virtually nil. The more negative differentials in emerging than in advanced economies is a phenomenon of 1975-1995, a period in which the advanced economies liberalized their capital markets, allowing interest rates to rise faster than inflation, whereas the emerging economies continued to use financial repression to constrain the rise in nominal interest rates against the background of increasing inflation. Prior to the mid-1970s, the advanced economies engaged in financial repression too. By the mid-1990s, many emerging economies had also liberalized their financial markets. 
To assess the role of financial repression systematically, we begin by identifying the financial repression and liberalization years, based on both de jure measures from Abiad et al. (2008) and de facto measures as the structural breaks in the UIP deviations (see "Appendix 2" for more details). Utilizing the identified liberalization years, as a first look, we examine whether financial repression has constrained interest-growth differentials. Essentially, we estimate the gap between the interestgrowth differentials before and after financial market liberalization using the following local projection specification on a 5-year horizon:

$$
(r-g)_{i t+j}=\beta_{j} D_{i t}+\gamma D_{i t-1}+\Gamma \mathbf{X}_{i t}+\alpha_{i}+\epsilon_{i t}
$$

where $j=1, \ldots, 5$, indicating the number of years after financial liberalization. $D_{i t}$ denotes dummies for whether financial repression is liberalized in country $i$ in year $t$ or not, and $\mathbf{X}$ includes the real interest rate (for serial correlation), real growth (for business cycle conditions), the change in public debt and initial public debt (for fiscal conditions), as well as commodity prices and Moody's BAA spreads (for global shocks and risks).

Financial repression years are indeed associated with significantly lower differentials, by 2 to 6 percentage points depending on the type of financial liberalization and the length of post-liberalization time. We explore different types of financial repression-interest controls, capital controls, and credit controls - and the de facto measure based on structural breaks in UIP deviations. As presented in Fig. 4, several features stand out. First, the liberalization's effect takes time to be reflected in an increase in interest-growth differentials. For instance, none of the liberalization shows impacts on interest-growth differentials contemporaneously. For interest rate controls and credit controls liberalizations, differentials do not increase until 2 years later, and at least 1 year for capital control liberalization and de facto liberalization measure. Second, the effects are long-lasting and remain significant after 5 years. Third, the de jure and the de facto measures arrive at similar results in the estimates' magnitudes.

Having established that financial repression constrains interest-growth differentials, we further explore the channel through which financial repression operates. Based on the previous results that the divergence between advanced and emerging economies mainly arises from emerging economies' high inflation and their subdued interest rate response to high inflation, we are particularly interested in how financial repression suppresses the response of interest rates to inflation. To this end, we use a specification that includes the interaction of financial repression and expected inflation. $^{10}$

$$
y_{i t}=\beta_{0} F R_{i t}+\beta_{1} F R_{i t} \times \pi_{i t}^{e}+\Gamma \mathbf{X}_{i t}+\alpha_{i}+\epsilon_{i t}
$$

\footnotetext{
${ }^{10}$ Financial repression constrains the response of interest rate to expected inflation; however, the response of the interest rate to unexpected inflation does not depend on whether financial repression is present.
} 

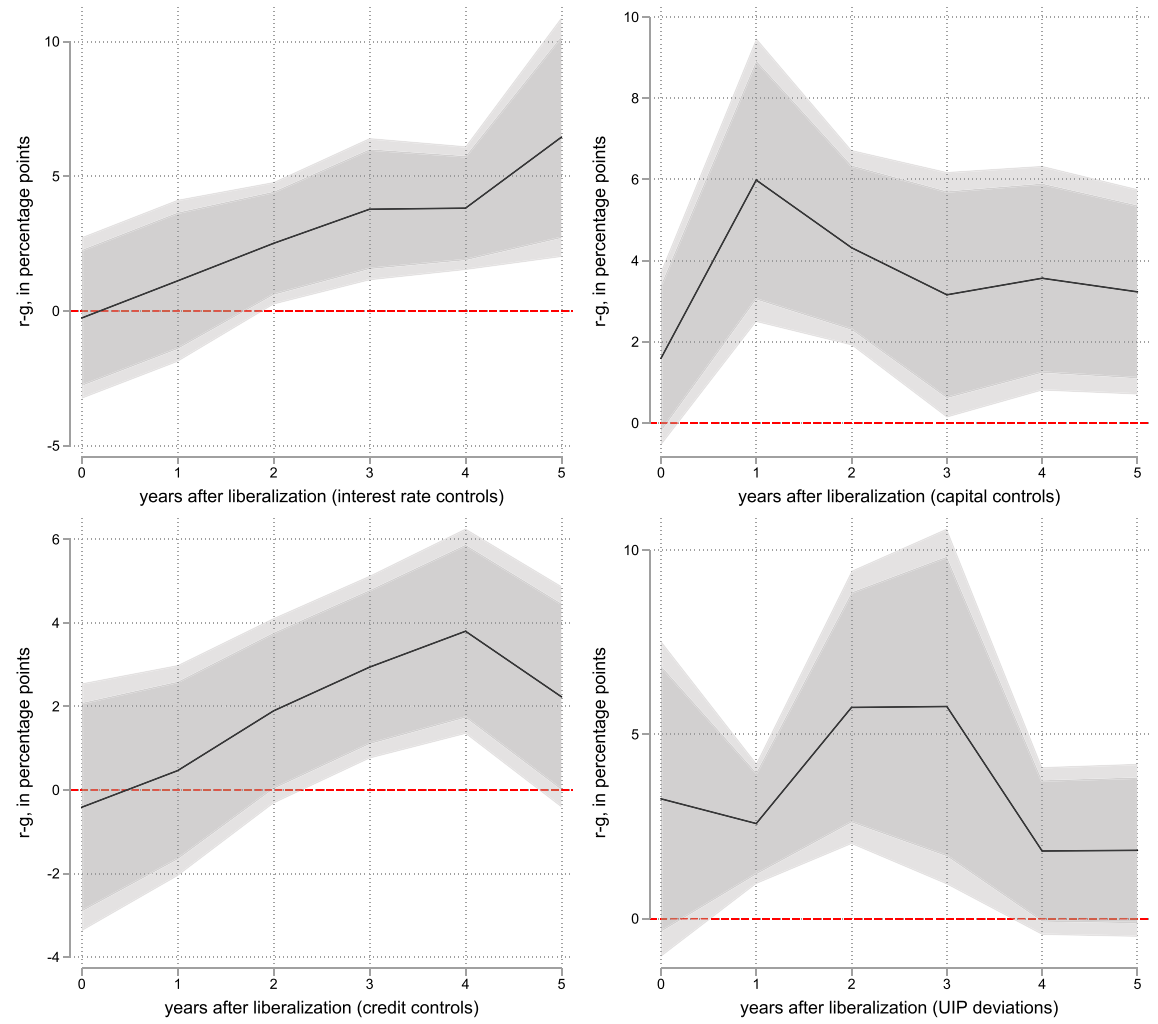

Fig. 4 Interest-growth differentials after financial liberalization, local projection. Note This chart plots the changes in interest-growth differentials after financial liberalizations, based on local projection. Financial liberalizations are measured by de jure measures-interest rate controls removal, capital controls removal, and credit controls removal, respectively. De facto measure is also included (right lower corner panel), measured by structural breaks in the deviations to the uncovered interest rate parity. The shaded areas indicate $95 \%$ (the lighter) and 90\% (the darker) confidence intervals, respectively

As financial repression mostly affects interest rates, we explore its impact not only on interest-growth differentials but also, in separate regressions, on effective, longterm domestic, and short-term domestic interest rates. These different dependent variables are denoted by $y_{i t}{ }^{11}$ We utilize the continuous financial repression indexes from Abiad et al. (2008) and the Chinn-Ito index, denoted by $F R$. The control variables $\mathbf{X}$ are the same as before. As contemporaneous inflation is a mismeasured proxy for expected inflation, we use lagged inflation as its instrument. ${ }^{12}$

\footnotetext{
11 Long-term rate is the 10-year treasury bill rate, and short-term rate is the 3 -month treasury bill rate. For the few countries whose 10-year rates are not available, 5-year or 2-year rates are used instead.

12 Lagged inflation can serve as a valid instrument for expected inflation (McCallum 1976): Under the assumption of rational expectations, realized inflation $\pi_{t}$ is equal to the sum of expected inflation $\pi_{t}^{e}$ and a white noise $u_{t}$. Therefore, $\pi_{t-1}$ is correlated with $\pi_{t}^{e}$ and uncorrelated with $u_{t}$.
} 


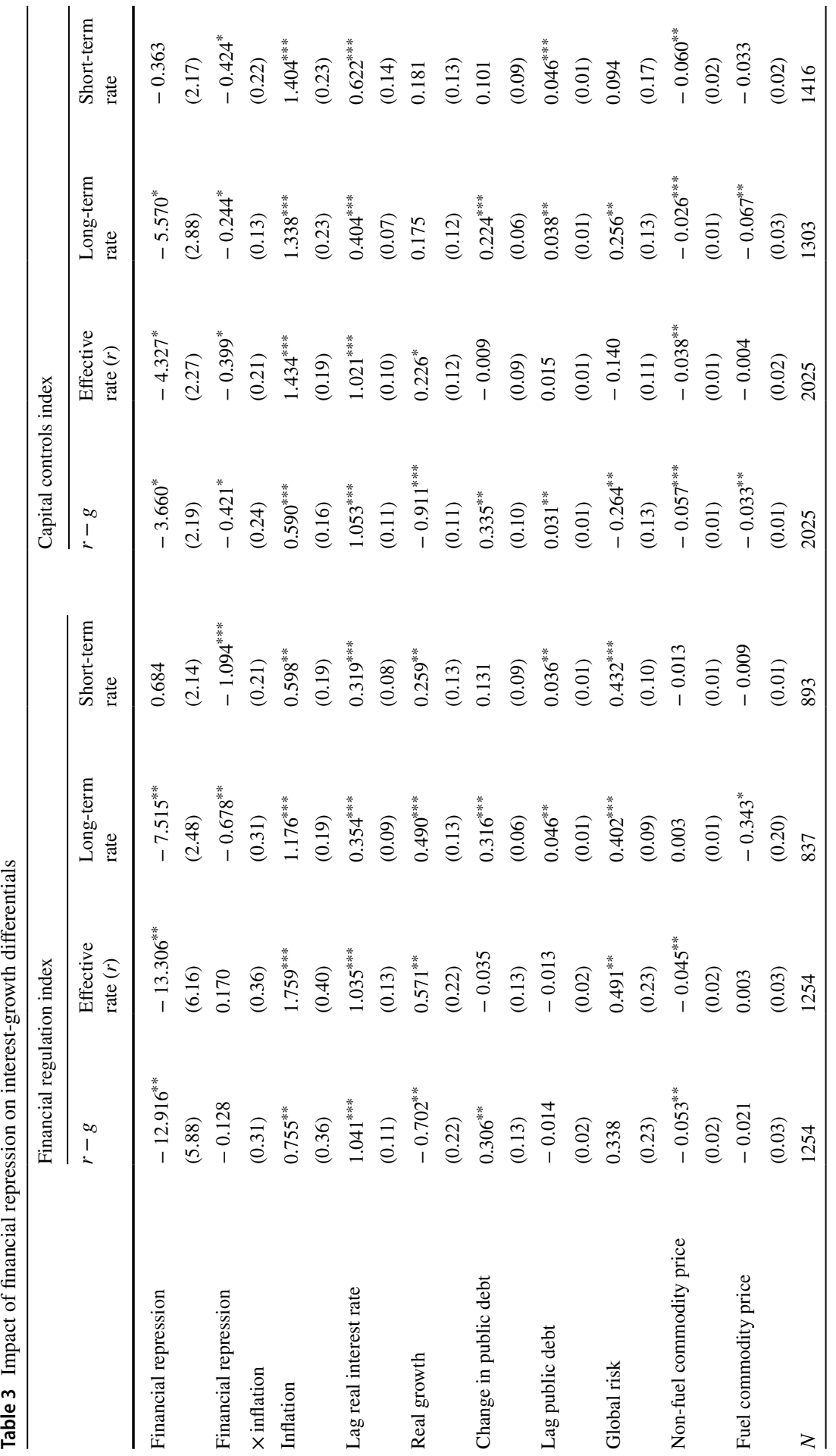




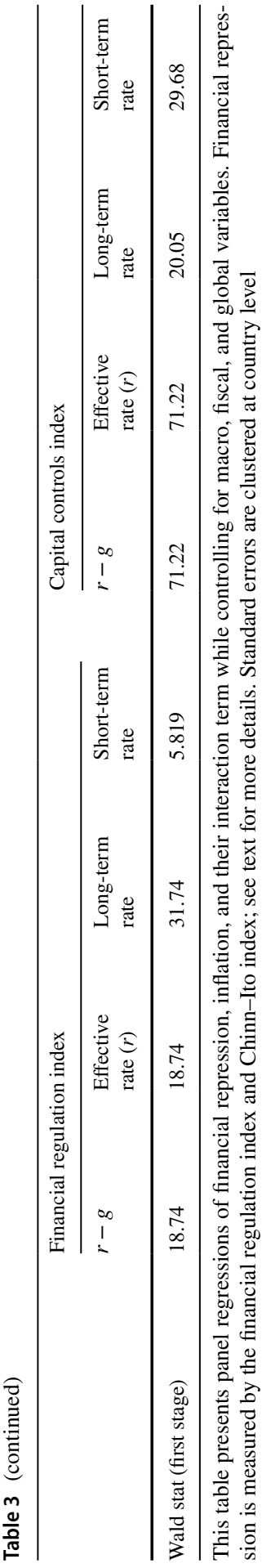

称 
In general, financial repression significantly suppresses the nominal interest rate and constrains its response to expected inflation, leading to low differentials (Table 3). Financial repression reduces nominal interest rates and differentials significantly: A one standard deviation deterioration in the financial regulation index is associated with a decrease in nominal interest rates and differentials by about 3 percentage points. These estimates also align with the literature. For instance, using a dynamic panel setting for a sample of 128 countries over 1999-2008, Escolano et al. (2017) estimate the coefficient on the Chinn-Ito capital control index to be around 4. Moreover, the responses of interest rates to expected inflation are muted by financial repression: Associated with an expected 1 percentage point inflation increase, the rise in effective rates is 0.4 percentage points lower for the most financially repressed country (based on mean Chinn-Ito index) than for the least country. Among different types of interest rates, the role of financial repression is most prominent in long-term domestic interest rates, because financial repression constrains long-term domestic interest rates by a greater extent than both effective rates, which contain external interest rates or short-term rates that may not be high enough to be affected.

Based on our estimates, the effective interest rate gap between advanced and emerging economies would have been reduced by 1.8 percentage points (out of 3.9 percentage points), on average, if emerging countries aligned with the median level of advanced economies' financial repression (measured by the financial reform index), thus allowing interest rates to change freely in response to economic fluctuations and move toward the level of advanced economies. ${ }^{13}$

To sum up, negative interest-growth differentials are a common occurrence in countries at all levels of economic development. The presumption-common in policy circles - that negative differentials are a phenomenon associated with emerging economies seems to be driven by the experience of 1975-1995 and does not stand up to scrutiny when considering longer historical periods.

\section{Interest-Growth Differentials, Fiscal Variables, and Sovereign Defaults}

Having reviewed the stylized facts on the levels of, and variation in, interest-growth differentials, we now turn to analyzing their implications for government debt sustainability. As changes in the public debt ratio are determined by both interestgrowth differentials (multiplied by the debt ratio) and the primary fiscal balance, it is important to consider not only these two items separately, but also the extent

\footnotetext{
13 One caveat is that our experiment here only aligns financial repression conditions between the two country groups - the other factors, including inflation and fiscal variables, stay the same. Therefore, the 1.8 percentage points represent the partial effects of financial liberalization in emerging countries as if they resemble advanced economies, controlling for any general equilibrium effects stemming from financial liberalization.
} 
Table 4 Correlations between interest-growth differentials and fiscal stance

\begin{tabular}{lcl}
\hline & Primary balance & $\begin{array}{l}\text { Cyclically } \\
\text { adjusted primary } \\
\text { balance }\end{array}$ \\
\hline$r-g$ & -0.03 & 0.15 \\
Real $r$ & 0.03 & 0.14 \\
Real $g$ & 0.09 & -0.03 \\
\hline
\end{tabular}

This table reports the median (across countries) of the country-specific correlations between interest-growth differentials and primary balances. The sample contains 55 countries and 4257 observations

to which they move together: In principle, a decline in differentials could be more than offset by an increase in the primary fiscal deficit. Therefore, in this section, we explore the empirical association between differentials and fiscal variables, before turning to the analysis of whether interest-growth differentials or fiscal variables are significantly different in the run-up to sovereign defaults compared with normal times.

\subsection{Interest-Growth Differentials and the Fiscal Stance}

Considering the whole sample, interest-growth differentials are (marginally) negatively associated with the primary fiscal balance, with a correlation coefficient of -0.03 (Table 4). (This is the median across countries of the country-specific correlation coefficients.) On the basis of this simple correlation, there is tentative evidence that policymakers respond to declining differentials with a slight expansion of primary fiscal deficits, but almost certainly not enough to fully offset the favorable impact of lower differentials. Even so, it is worth exploring these potential relationships somewhat further. The correlation of the primary fiscal balance is significantly positive with economic growth, reflecting the well-known positive association between fiscal revenues and economic growth; the correlation of the primary fiscal balance and interest rates is weaker, albeit positive, perhaps as governments tighten fiscal policies when borrowing costs are higher.

The association between the differentials and the cyclically adjusted fiscal balance $^{14}$ is positive and significant, with a correlation coefficient of $0.15(0.14$ with the real interest rate, suggesting a policy response to borrowing costs, and -0.03 with real growth, suggesting slightly countercyclical fiscal policies). ${ }^{15}$ Two caveats are in order when interpreting these correlations: First, the sample consists of countries at

\footnotetext{
${ }^{14}$ The cyclically adjusted primary balance is calculated as: $p b^{c a}=p b-e \alpha$, where $p b$ denotes primary balance, $p b^{c a}$ denotes cyclically adjusted primary balance, and $e$ denotes spending, all as share of GDP. $\alpha$ denotes the nominal output gap. In other words, we assume the revenue elasticity to be one and the spending elasticity to be zero, in line with the estimates in Girouard and André (2005). Even so, cyclical adjustment must be interpreted cautiously, especially for emerging economies, because the business cycle fluctuations in emerging economies are primarily driven by shocks in trend economic growth (Aguiar and Gopinath 2007).

${ }^{15}$ Here, we abstract from the depreciation adjustment as its correlation with the differentials is found to be negligible.
} 
Table 5 Decomposing the correlations between interest-growth differentials and fiscal stance

\begin{tabular}{lllccr}
\hline & $\operatorname{corr}\left(p b^{c a}, r-g\right)$ & $\operatorname{corr}\left(p b^{c a}, r\right)$ & $\frac{\sigma_{r}}{\sigma_{r-g}}$ & $\operatorname{corr}\left(p b^{c a}, g\right)$ & $\frac{\sigma_{g}}{\sigma_{r-g}}$ \\
\hline Full sample & 0.19 & 0.21 & 0.88 & -0.03 & 0.45 \\
Advanced Economies & 0.22 & 0.25 & 0.87 & -0.03 & 0.50 \\
Emerging Economies & 0.14 & 0.15 & 0.89 & -0.02 & 0.36 \\
\hline
\end{tabular}

This table decomposes the correlations between interest-growth differentials and cyclically adjusted primary balance, and the mean of the country-specific correlations are reported. See the main text for details on the decomposition. The sample contains 55 countries and 4257 observations

different levels of economic development and financial integration in international capital markets over long historical periods; second, cyclical adjustment of fiscal variables is difficult in the presence of changes in trend economic growth-an especially relevant consideration for emerging economies.

To see whether the correlation with real growth or real interest rate drives the overall correlation between differentials and cyclically adjusted primary balance, we decompose the correlation as follows:

$$
\operatorname{corr}\left(p b^{c a}, r-g\right)=\operatorname{corr}\left(p b^{c a}, r\right) \cdot \frac{\sigma_{r}}{\sigma_{r-g}}-\operatorname{corr}\left(p b^{c a}, g\right) \cdot \frac{\sigma_{g}}{\sigma_{r-g}}
$$

The overall correlation is the difference between the correlations of each component adjusted by the standard deviation (denoted by $\sigma$ ) ratios. As reported in Table 5, the real interest rate plays the dominant role in the overall correlation, showing both higher correlation with cyclically adjusted primary balance and higher standard deviation relative to that of interest-growth differentials. Advanced economies have a higher correlation than the emerging economies between the real interest rate and the cyclically adjusted primary balance, which indicates that fiscal expansions in advanced economies when real interest rates are low exceeds those of emerging economies.

To explore the conditional relationship between interest-growth differentials and the primary balance, we estimate the fiscal response function following studies such as Bohn (2008) and Mauro et al. (2015) to include the role of interest-growth differentials. The regression is specified as

$$
p b_{i t}=\beta_{1} d_{i t-1}+\beta_{2}(r-g)_{i t}+\beta_{3} d_{i t-1} \times(r-g)_{i t}+\Gamma \mathbf{X}_{i t}+\alpha_{i}+\epsilon_{i t}
$$

where $p b$ denotes the primary balance and $d$ is the public debt, both as a share of GDP, and $\mathbf{X}$ includes the real output gap, the real public spending gap, and commodity prices, varying in different specifications. ${ }^{16}$

\footnotetext{
16 The real output gap and public spending gap are the HP-filtered cyclical components of the logarithm real GDP and logarithm real public spending, representing the percent deviation from their trends, respectively. Real public spending is the nominal spending deflated by GDP deflator.
} 
Table 6 Primary balance response functions and interest-growth differentials

\begin{tabular}{lllllll}
\hline & $(1)$ & $(2)$ & $(3)$ & $(4)$ & $(5)$ & $(6)$ \\
\hline Lag public debt & $0.010^{*}$ & $0.010^{*}$ & & $0.012^{* *}$ & $0.011^{* *}$ & $0.011^{* *}$ \\
& $(0.01)$ & $(0.01)$ & & $(0.01)$ & $(0.01)$ & $(0.01)$ \\
Lag public debt $\times(r-g)$ & & & $0.001^{* *}$ & $0.001^{* *}$ & $0.001^{* *}$ & $0.001^{* *}$ \\
& & & $(0.00)$ & $(0.00)$ & $(0.00)$ & $(0.00)$ \\
$r-g$ & & & & -0.003 & -0.000 & -0.000 \\
& & & & $(0.01)$ & $(0.01)$ & $(0.01)$ \\
Real output gap & & 0.076 & & & $0.117^{* *}$ & $0.118^{* *}$ \\
& & $(0.05)$ & & & $(0.05)$ & $(0.05)$ \\
Real spending gap & & $-0.100^{* * *}$ & & & $-0.103^{* * *}$ & $-0.103^{* * *}$ \\
& & $(0.02)$ & & & $(0.02)$ & $(0.02)$ \\
Non-fuel commodity price & & & & & & 0.001 \\
& & & & & & $(0.00)$ \\
Fuel commodity price & & & & & & -0.005 \\
& & & & & & \\
$N$ & 4007 & 4007 & 4007 & 4007 & 4007 & 4007 \\
$R^{2}$ & 0.008 & 0.111 & 0.014 & 0.024 & 0.133 & 0.133 \\
\hline
\end{tabular}

This table presents panel regressions of primary balance (as share of GDP) response functions. Column (1) and (2) are the baseline fiscal response functions in the literature. Column (3) to (6) augment fiscal response functions with lagged public debt, $r-g$, and interaction term, in various forms. Standard errors are clustered at country level, also allowing for cross-sectional dependence

The primary fiscal balance is tighter when interest-growth differentials are higher, with the magnitude of tightening increasing with initial debt level (Table 6). We first replicate Bohn (2008), and the results align with the literature - a 10 percent increase in the debt-to-GDP ratio is associated with a 0.1 percent of GDP primary balance tightening. With interest-growth differentials included, we find that the coefficient of the interaction between debt and differentials is significantly positive; however, the magnitude is not high enough to offset the direct impact of differentials on debt servicing cost. Considering, for instance, a country with a $100 \%$ debt-to-GDP ratio, a 100 basis points decrease in differentials is associated with an expansion in the primary fiscal balance by 0.1 percent of GDP, far less than the beneficial impact on the debt ratio (1 percent of GDP) that stems through the accounting relationship from the lower differential times the debt ratio. In other words, taking these empirical associations at face value, policymakers would seem to respond to lower differentials by expanding the primary fiscal deficit, but not nearly enough to offset the direct beneficial impact of lower differentials on the debt ratio. 


\subsection{Interest-Growth Differentials in the Run-Up to Default Episodes}

Having explored whether the impact of changes in interest-growth differentials on debt dynamics can be attenuated by fiscal responses, we now analyze whether unfavorable differentials are associated with sovereign defaults. We focus on whether differentials are higher in the run-up to defaults than in "normal times," using an approach similar to Gourinchas and Obstfeld (2012). We define "normal times" as all years except: (1) those when the country is in default, (2) the 3 years after the completion of debt restructuring, or (3) the 5 years prior to default. The estimated equation is as follows:

$$
y_{i t}=\sum_{j=1}^{5} \beta_{j} D_{i t}^{j}+\lambda_{t}+\alpha_{i}+\epsilon_{i t}, \quad y \text { denotes } r-g, r, g, \text { debt, etc. }
$$

where $y$ denotes interest-growth differential, effective interest rate, growth, primary deficit, or any variable of interest as shown in Fig. $5, D_{i t}^{j}$ denotes $j$ years before default, and $\alpha_{i}$ and $\lambda_{t}$ denote country and year fixed effects, respectively. Besides the country fixed effects as in Gourinchas and Obstfeld (2012), we also include year fixed effects to control for any global factors that may affect interest-growth differentials, such as shocks to global risk aversion. The estimates of $\beta_{1}, \ldots, \beta_{5}$ are presented in Fig. 5.

We cannot reject the null hypothesis that interest-growth differential levels in the years prior to default are the same as in normal times. This result holds in the full sample, as well as the postwar, advanced economies, and emerging economies subsamples. Further decomposition of interest-growth differentials into components shows that real interest rates are somewhat lower than usual, albeit not significantly $;{ }^{17}$ and that real economic growth is significantly lower than usual the year prior to default. Considering changes over time, there is a noticeable increase in interest-growth differentials, fully accounted for by a growth deceleration. Five years prior to default, the interest-growth differential is significantly (and perhaps counterintuitively) lower than the norm; it then gradually rises into positive-but not significantly positive-territory the year prior to default. Meanwhile, economic growth is above the norm 5 years prior to default, and gradually declines to be significantly below the norm the year prior to default. A tentative and speculative interpretation of this observed pattern could be that defaults are preceded by a boom-bust cycle in economic growth.

Sovereign defaults in emerging countries are often just preceded or accompanied by large depreciation, which could boost the debt ratio. To take account of this effect, we assess the differences in depreciation adjustment between the run-up to default and normal times in the same specification as before. The results (Fig. 5) show that depreciations are, on average, 20 percent larger in the year prior to default compared with normal times. This leads to higher depreciation adjustment, 8.8 percentage points 1 year prior to default, significant at the $90 \%$ level. However,

\footnotetext{
${ }^{17}$ Inflation is calculated using the GDP deflator, and the (ex post) real interest rate is the nominal rate adjusted for this period's inflation.
} 

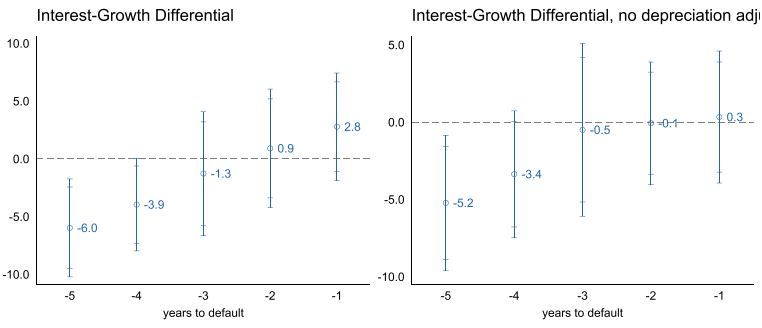

Interest-Growth Differential: Subsamples
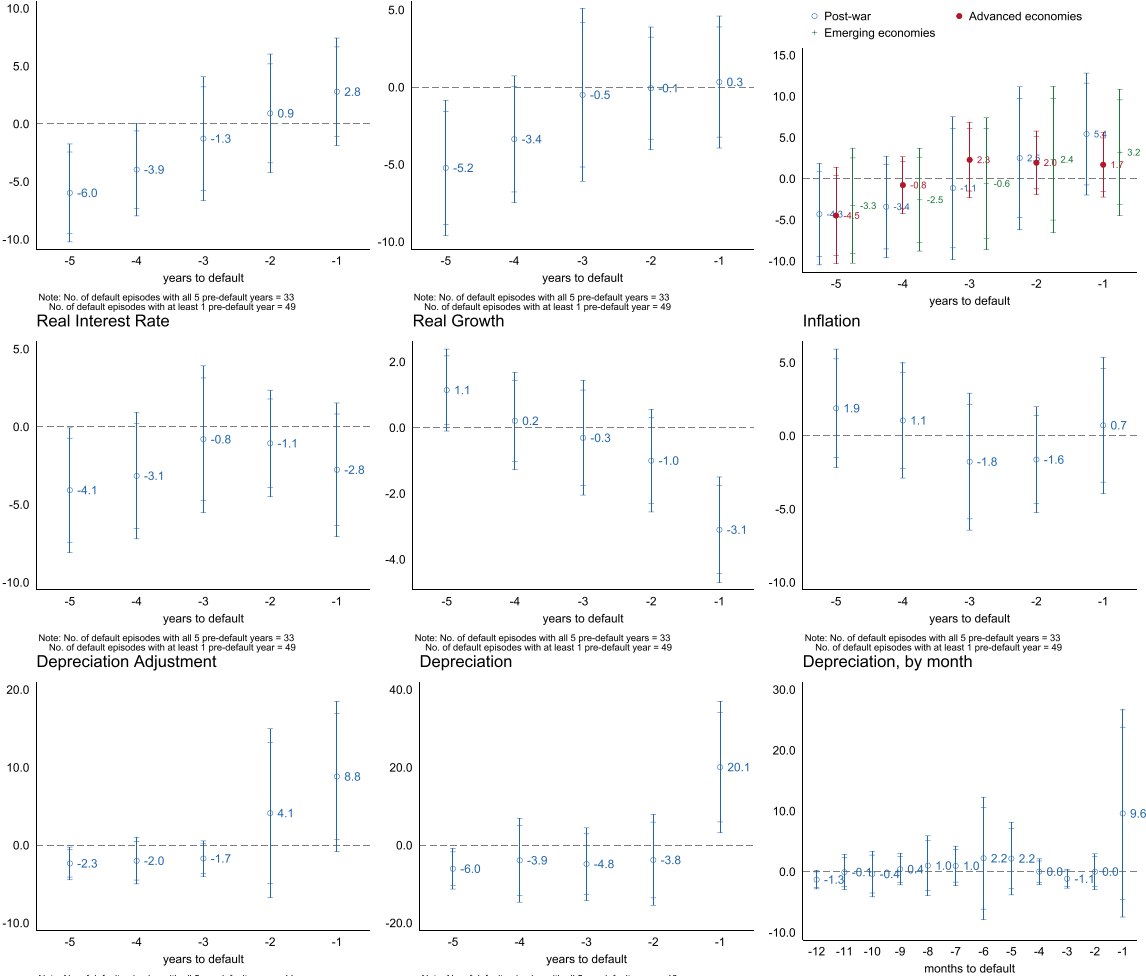

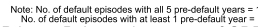

No. of defautit episodes with at least 1 pre-defaulul year $=1$
Primary Balance, in percent of GDP

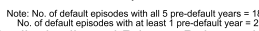

No. of deftaut episodes with at last pre-detaut year $=27$
Cyclical-adjusted Primary Balance, in percent of

Note: No. of defaut episodes $=12$
Public Debt, in percent of GDP
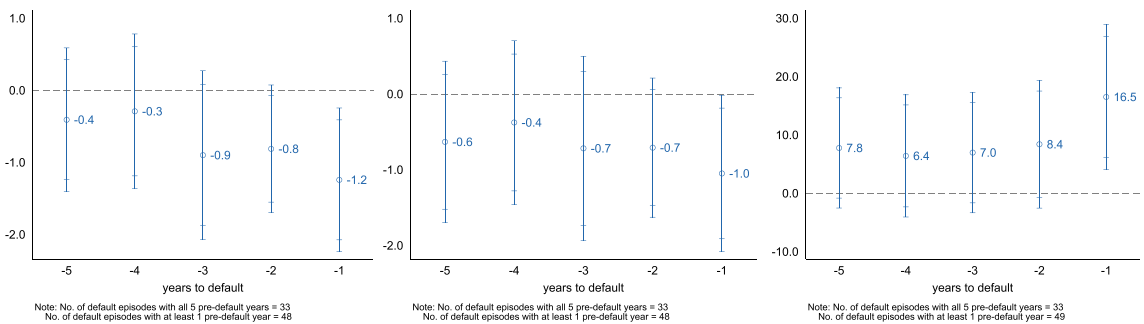

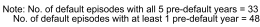

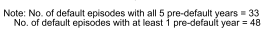

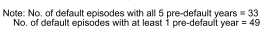

Fig. 5 Interest-growth differentials and fiscal variables in the run-up to sovereign default. Note This chart plots the interest-growth differentials, the real interest rate, the inflation, the real growth, the exchange rate depreciations, the primary fiscal balance, and public debt as share of GDP in the run-up to sovereign default. The point estimate is the value in years before the onset of sovereign default compared with normal years, controlling for country and year fixed effects. Debt restructuring years and (3 years) post-debt restructuring years are dropped from the sample. The sample contains 27 sovereign default episodes for annual depreciation-related variables, 12 for monthly depreciation, and 49 for the rest. The narrower and wider bands indicate the $90 \%$ and $95 \%$ confidence intervals, respectively 
zooming into the months preceding default reveals that visibly large depreciationsalbeit insignificant—-do not show up until a few months prior to default.

Turning to the fiscal policy variables, both primary deficits and public debts are larger than usual in the year before default. In part, this is because economic growth is lower than usual the year before default, with adverse effects on revenues and thus the primary deficit, as well as on the denominator in the debt-to-GDP ratio. Specifically, in the year prior to default, the primary fiscal balance is about 1 percent of GDP lower than in normal times, even after teasing out the cyclical component. In the meantime, public debt is 16 percent higher, as share of GDP.

On the whole, these results suggest that interest-growth differential levels do not help to predict defaults, whereas primary deficits and public debt ratios seem to have some predictive power. There are also tentative signs that declines in economic growth often precede defaults. These results are consistent with those by Moreno Badia et al. (2020), who reach similar conclusions using a machine learning method in the context of an early warning system for fiscal crises, based on a large sample of countries and more than 100 variables over a shorter sample period.

\subsection{Marginal Rates in the Run-Up to Default Episodes}

The marginal interest rate responds faster than the average effective rate to changes in market sentiments. There is abundant evidence documenting the increase in marginal rates in the run-up to defaults. For instance, in the cases of Greece, Argentina, Dominican Republic, etc. (Fig. 6), marginal rates skyrocketed in the run-up to default. ${ }^{18} \mathrm{~A}$ similar pattern is observed in more distant default episodes such as Uruguay in 1876 and Greece in 1894 (Fig. 7).

Averaging across all default episodes, marginal rates in the run-up to defaults exceed those in normal times by about 2 percentage points, and the differences are statistically significant (Fig. 8). This pattern holds for marginal rates measured on both domestic currency borrowing and foreign currency borrowing, and it is slightly more pronounced on the foreign currency portion.

Although the marginal rate increases sharply preceding sovereign defaults, it does not give much time for policymakers to react. Unpacking the year before default into months (Fig. 9), sizable gaps emerge about six months before default, and they keep growing as default approaches. However, the increases are not robustly significant until two months prior to default. Therefore, marginal rates do not buy much time for corrective policy measures to take place.

\footnotetext{
${ }^{18}$ The marginal rates are calculated as 10-year treasury bond yields for Greece and EMBI spread plus the US 10-year treasury yields for emerging markets.
} 

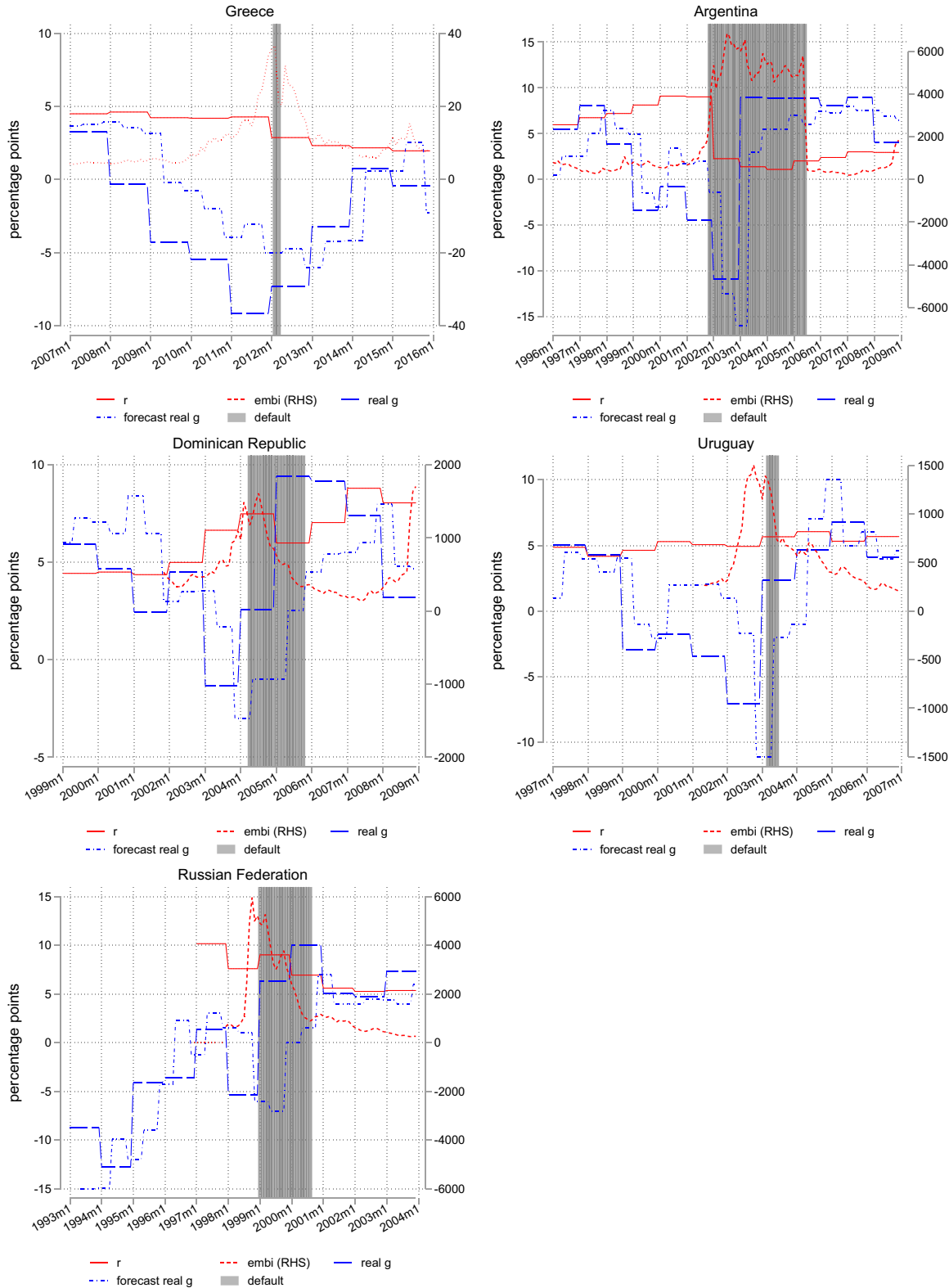

Fig. 6 Dynamics of marginal interest rate during recent sovereign default episodes. Note This chart plots the evolution of marginal interest rate during recent sovereign default episodes. The margin interest rate is the sum of sovereign bond EMBI spread and the US 10-year treasury bond yield 

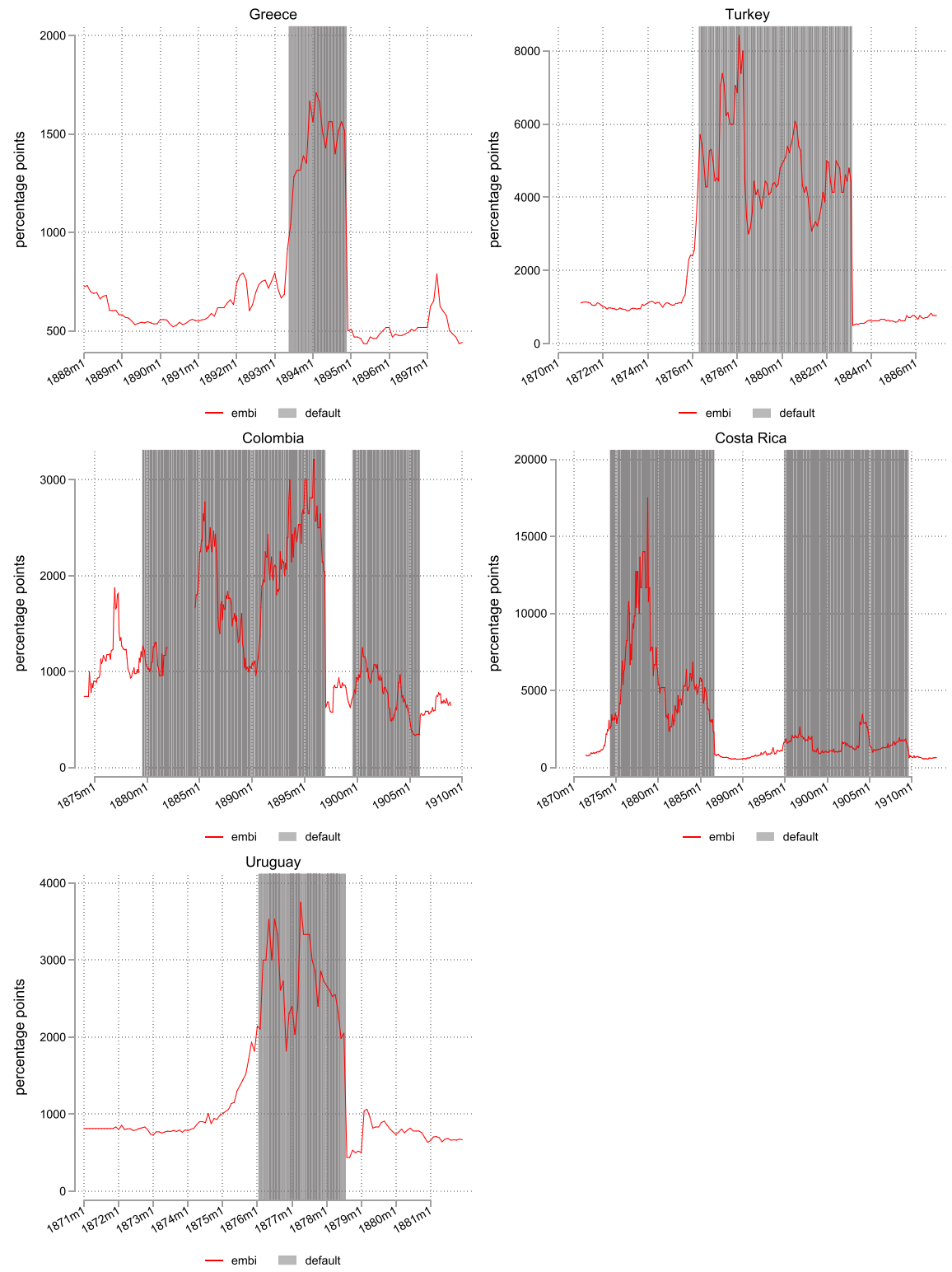

Fig. 7 Dynamics of marginal interest rate during historical sovereign default episodes. Note This chart plots the evolution of marginal interest rate during historical sovereign default episodes before 1930s. The margin interest rate is the sum of sovereign bond spread and the consol bond rate 


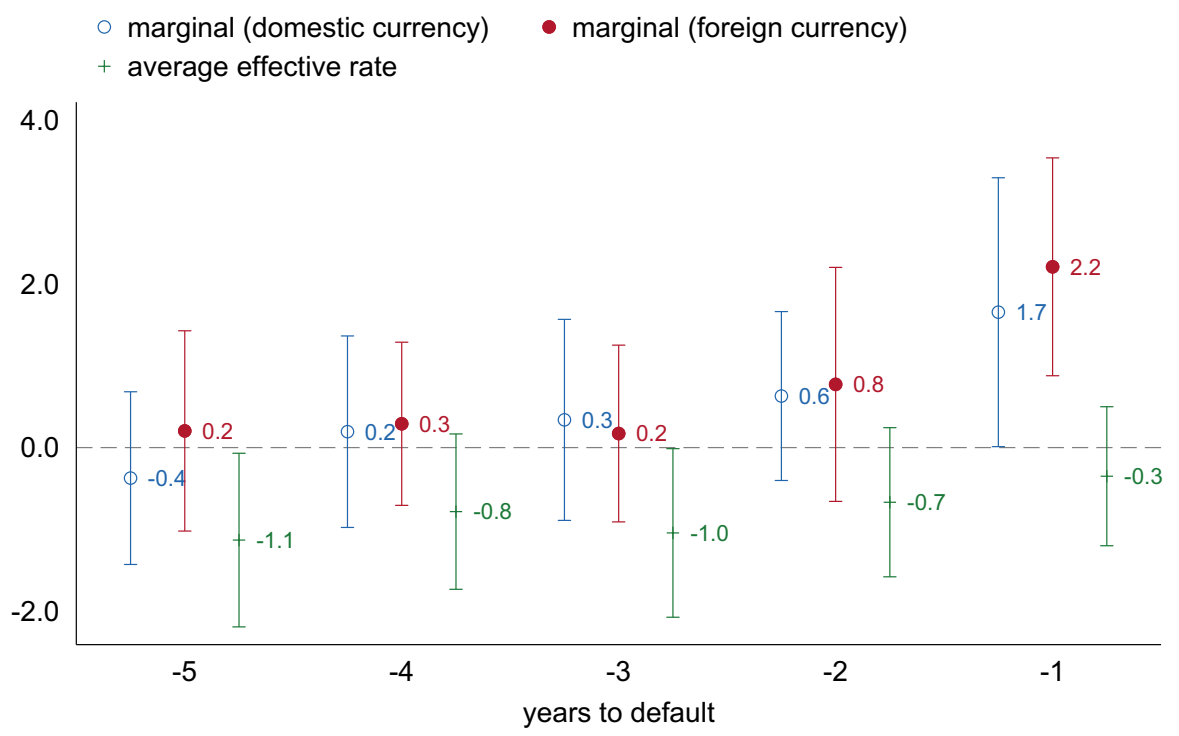

Note: No. of default episodes with domestic marginal rates in all 5 pre-default years $=17$, foreign $=13$ No. of default episodes with domestic marginal rates in at least 1 pre-default year $=21$, foreign $=22$

Fig. 8 Marginal interest rates in the run-up to sovereign default. Note This chart plots the marginal interest rates in the run-up to sovereign default. Domestic marginal rates are the 10-year treasury bond yields, and foreign marginal rates are the sum of EMBI spreads and 10-year US treasury bond yields. The point estimate is the value in years before the onset of sovereign default compared with normal years, controlling for country and year fixed effects. Debt restructuring years and (3 years) post-debt restructuring years are dropped from the sample. The band indicates the $95 \%$ confidence interval

To recall, the average effective interest rate is the relevant rate to determine debt dynamics. The marginal rate, which measures the borrowing cost for new issuance, reflects market sentiments more quickly, but is an imperfect proxy for future developments in the average effective interest rate. The marginal rates are only relevant for debt dynamics when changes in sentiments are sustained for a long time and such changes affect the whole maturity structure of the debt. The marginal rate is, more importantly, a reflection of whether investors are willing to roll over the debt. Increases in the marginal rate are the mirror image of a default triggered by a change in market sentiment, which is in turn hard to predict. Fiscal variables such as debts and deficits have some predictive power, but average effective interest-growth differentials do not.

\section{Conclusion}

Our empirical analysis of interest-growth differentials and their role in public finance is relevant from the standpoint of economic models, which usually assume that the interest rate exceeds the rate of growth of the economy. It is also relevant from perspective of policymaking, especially against the backdrop of 


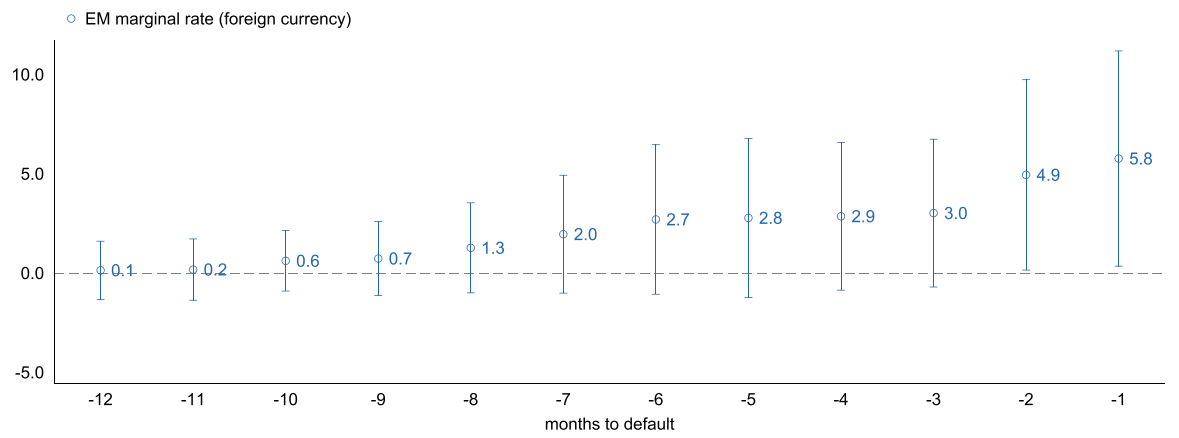

Fig. 9 Marginal interest rates in the run-up to sovereign default, by month. Note This chart plots the marginal rates in the twelve months preceding sovereign default. The sample covers 15 default episodes, 8 cases in the late 1800 s and early 1900 s, and the rest in the post- 1985 years. The point is the value in months before the onset of sovereign default compared with normal months, controlling for country and year fixed effects. In-default months and 3 years post-debt restructuring are dropped out from the sample. The band indicates the $95 \%$ confidence interval

two features of the post-GFC setting: the prevalence of low and often negative interest-growth differentials and high public debt ratios. We find that the negative differentials experienced between the GFC and the 2020 economic collapse caused by the COVID-19 pandemic are not unprecedented. On the contrary, they prevail in the history of both advanced and emerging economies. Negative differentials are, if anything, the norm rather than the exception during the past two centuries. Moreover, low differentials based on average effective interest rates are not associated with lower frequency of sovereign defaults, whereas fiscal deficits and debts as well as declines in economic growth seem to have some (albeit limited) predictive power for sovereign defaults.

In view of these findings, should low differentials-when they return-allow us to sleep more soundly? Based on the findings reported in this paper, our answer is: perhaps a little, but not really. Sovereign default histories demonstrate that after prolonged periods of low differentials based on average effective interest rates, marginal borrowing costs can rise suddenly and sharply, shutting countries out of financial markets at short notice.

Our paper has abstracted from analyzing a full set of exogenous contributors to interest-growth differentials. A more complete analysis would require taking into consideration the reasons why interest-growth differentials are currently so low, as pointed out, for example, by Garín et al. (2019). Our objective has been to caution that negative differentials do not necessarily reduce the likelihood of government defaults in the years ahead. Only with further reflection on the factors underlying the low differentials, as well as prospects for the primary fiscal balance, will we be able to make fully informed judgments on an appropriate stance of policies.

Acknowledgements We gratefully acknowledge helpful suggestions by Philip Barrett, Olivier Blanchard, Julio Escolano, Jean Marc Fournier, Vitor Gaspar, Ethan Ilzetzki, Catherine Pattillo, Andrea Presbitero, Kenneth Rogoff, and participants in the IMF's 2019 Annual Research Conference. We thank S. Ali Abbas and Kunxiang Diao for sharing the external public debt data. 


\section{Appendix 1: Data Appendix}

\section{Fiscal Variables}

The centerpiece of our data consists of fiscal variables and, in particular, the interest bill from which we compute the effective interest rate on government debt, covering an unbalanced panel of 55 countries (24 advanced economies and 31 emerging economies, using the present-day classification from the IMF's World Economic Outlook classification) over $1800-2018 .^{19}$

An important issue in the construction of long-term fiscal data series relates to the choice of government sector coverage. In order to refer to the most comprehensive sector of government for which they were available, the data at the general government level are collected wherever available. In most cases, general government data are unavailable before 1960 — not surprisingly, given that for most countries the share of spending by subnational governments has risen significantly only since then. As a result, the sector reported switches (in most cases, simultaneously for all variables-including the interest bill and the debt stock-for a given country) from central government to general government in nearly all final spliced series, and this switch generally happens in the 1960s or 1970s. Breaks in series are recorded in the database.

The average effective interest rate on debt is computed as the ratio of the interest bill in year $t$ to the stock of government debt (average of debt stocks of year-end $t$ and $t-1$ ) from the above sources. The marginal cost of borrowing (in most cases, yield to maturity on the secondary market) is compiled from Mauro et al. (2002, 2006) for 1870-1914 and data stream-updated to June 2019.

External public debt comes from a dataset assembled by the IMF staff using the WB-IMF Quarterly Public Sector Debt, OECD Central Government Debt, WEO, Jeanne and Guscina (2006), Morsy et al. (2007), Abbas and Christensen (2010), Abbas et al. (2010), and Abbas et al. (2014). We extend it back to 1970 using the World Bank's International Debt Statistics when possible.

\section{GDP}

For nominal GDP data from the distant past, the main sources are Mitchell and MOXLAD. For most countries, GDP data do not exist before World War I: In these

\footnotetext{
19 Half of the observations for the fiscal variables in the dataset are drawn from various cross-country sources, including the IMF's World Economic Outlook (WEO) and International Financial Statistics (IFS) and the OECD Analytical Database for the past 20-50 years (subject to availability); the Statistical Yearbooks of the League of Nations and the United Nations (as well as their Public Debt Supplements) for the period between World War I and the 1970s; and Flandreau and Zumer (2004) for the pre-World War I era; in addition, long-run historical series are drawn from Mitchell's International Historical Statistics and the Montevideo-Oxford Latin American Database (MOXLAD). The other half of the data is hand-collected from country-specific sources, such as official government publications or economic histories that included public finance statistics. Examples of such data sources include Fregert and Gustafsson (2005) for Sweden over 1800-2004; Fernandez and Acha (1976) for Spain over 1850-1975; and Junguito and Rincon (2004) for Colombia over 1923-2003.
} 
years, GDP is proxied by variables such as Gross National Product or Net National Product from Mitchell's International Historical Statistics. In a few cases, UN statistical yearbooks are used to fill in gaps in coverage between 1940 and 1975. GDP data are drawn from the OECD database for a few member countries beginning as early as 1960 . For some countries, such as the USA, the UK, Italy, the Netherlands, Japan, Canada, and India, GDP is based on government publications or other country-specific sources. Starting in the mid-1990s, GDP data for almost all countries are taken from the WEO. Many sources, both cross-country and country-specific, provided fiscal data already expressed in terms of GDP as well. To ensure the quality of our fiscal and GDP data, we cross-check with Jordà et al. (2017) for 17 advanced economies from 1870 to 2016.

Based on the fiscal variables and GDP data, the interest-growth differentials are calculated as the differences between average effective interest rates on debt and nominal growth rates. To take account of the revaluation impact of exchange rate depreciation on public debt denominated in foreign currency, we later allow for depreciation adjustment, and more details can be found in Sect. 3.3.

\section{Other Financial Variables}

Money market rates, exchange rate. Drawn from Global Financial Data. Money market rate is the 3-month treasury yield in the secondary market, and 3-month interbank overnight borrowing rate is used if 3-month treasury yield not available.

Sovereign defaults Years of default are drawn from Reinhart and Rogoff (2009) and, for 2009-2018, Moody's "Sovereign Default and Recovery Rates, 1983-2018" over 2009-2018. Months of default are from Mauro et al. (2002) and Asonuma and Trebesch (2016).

Financial repression Based on a dataset of financial reforms from Abiad et al. (2008), covering 91 countries since 1973. The database recognizes the multifaceted nature of financial reform and records financial policy changes along seven different dimensions: credit controls and reserve requirements, interest rate controls, entry barriers, state ownership, policies on securities markets, banking regulations, and restrictions on the capital account. Liberalization scores for each category are combined in a graded index that is normalized between zero and one.

\section{Appendix 2: Identify Financial Repression Years}

To analyze the role of financial repression in reducing debt cost, we being with identifying the financial repression years for each country. We employ both de jure and de facto measures. The de jure measures come from Abiad et al. (2008), as illustrated before, they cover inclusive aspects of financial sector policy such as interest rate controls and capital controls. We define the liberalization year as the first year that the index of interest rate controls and capital controls reach the highest category, meaning free market. For the case the index decreases after reaching the highest category, we set the most recent year when the highest value is first reached. 
Therefore, our estimates can be viewed as a lower bound. The de facto measures are the structural breaks in the UIP deviations, which we identify by applying Bai and Perron (1998). The motivation comes from that frictions in the financial market imposed by finance repression can lead to UIP deviations. We calculate the 3-month horizon UIP deviation using the second market yields of the sovereign bonds. We set the 3-month horizon as the 3-month interest rates provide the largest country and year coverage, and the 3-month provides sufficient frequency to identify structure breaks. Note that as we use the 3-month interest rates, their structure breaks are neither automatically nor substantially lead to structure breaks on the effective interest rate which is used in interest-growth differentials.

The de jure and the de facto measures complement each other and provide ways for cross-validation. The advantage of the de jure measures is that they are objectively defined by the change in the policy regulations. However, the available policy measures still miss certain types of financial repression. For instance, financial repression can take the non-legislated form, such as moral suasion by putting pressure on banks to extend material support to the government. For instance, in the late 1940s, the Bank of England can make recommendations to bankers to take actions in the public interest and if these recommendations were not followed, with the approval of the Treasury, to issue directions to any banker. The de facto measures are market-based, which are able to capture the changes in interest rate resulted from all explicit and implicit regulations. That said, there are a couple of challenges. First, the UIP deviation suffer from measurement errors because the expected exchange rate is unobservable. To minimize measurement errors in using the UIP deviations and work around the benchmark, we employ various approaches to calculate expected future exchange rates, namely, the actual exchange rate, last period's exchange rate, the average of last three periods, and the expected future exchange rate backed from the purchasing power parity. Second, as UIP usually does not hold, it is difficult to benchmark a counterfactual for no financial repression. Therefore, we only focus on the structure breaks rather than all deviations from UIP. The liberalization years identified by de facto measures are considerably close to those by the de jure. For instance, the median difference of the liberalization years between the UIP deviation and the capital controls abolishment is 2-year. Also, different measures of UIP deviation result in very similar liberalization years, with the largest difference of 2 years.

As presented in Fig. 10, the de jure measures show that there is a significant wave of financial liberalization starting from the early 1980s for advanced economies (earliest as 1963, latest as 1988) and from the late 1980s for emerging countries (earliest as 1974, latest as 2004). For instance, the Bank of England stopped publishing the Minimum Lending Rate in 1981, interest rates ceilings were abolished om 1967 in Canada, deposit rates were liberalized in 1988-89 in Mexico, and restrictions on capital movements were lifted after August 1989 in Turkey. By the end of 1990s, the majority of advanced economies have abolished interest controls and capital controls. The liberalization process in emerging economies is still ongoing. 


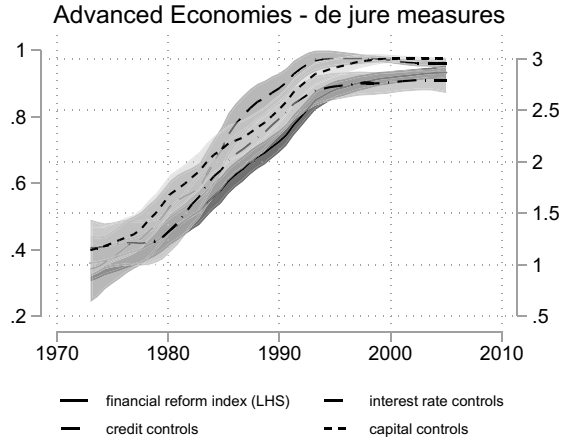

Emerging Economies - de jure measures

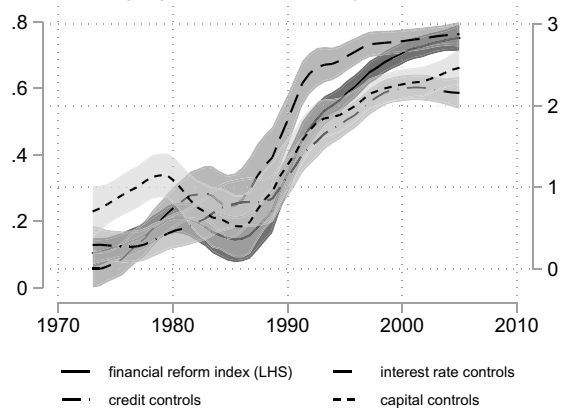

Advanced Economies - de facto measure

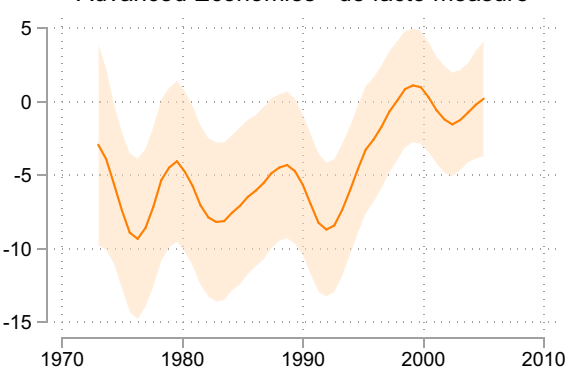

- - UIP deviations, scaled by intital value of each country

Emerging Economies - de facto measure

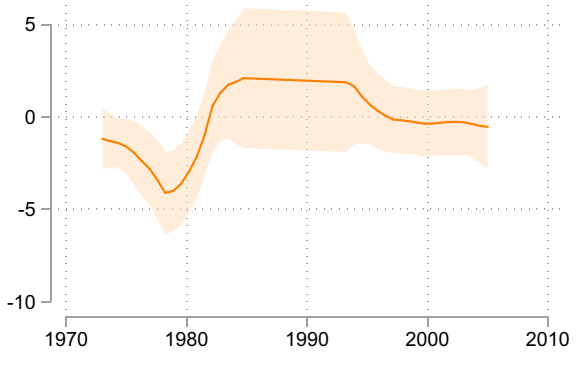

Fig. 10 Measures of financial liberalization. Note: This chart plots the average of financial repression measures across years. The de jure financial liberalization measures include interest rate controls, credit controls, capital controls, and an overall financial reform index. The de facto measure is minus of the uncovered interest parity deviation against USA, scaled by the deviation of each country at the beginning of the period. The shaded area is the $95 \%$ confidence band calculated by normal kernel smoothing. For all the indexes, the higher the value, the less the regulated

\section{References}

Abbas, Ali, Alex Pienkowski, and Kenneth Rogoff. 2019. Sovereign debt: A guide for economists and practitioners. Oxford: Oxford University Press.

Abbas, Ali, and Jakob E. Christensen. 2010. The role of domestic debt markets in economic growth: An empirical investigation for low-income countries and emerging markets. IMF Economic Review 57(1): 209-255.

Abbas, Ali, Laura Blattner, Mark De Broeck, Ms Asmaa El-Ganainy, and Malin Hu. 2014. Sovereign debt composition in advanced economies: A historical perspective. IMF Working Paper, 14/162.

Abbas, Ali, Nazim Belhocine, Asmaa A ElGanainy, and Mark Horton. 2010. A historical public debt database. IMF Working Paper, 1/26.

Abel, Andrew B., N. Gregory Mankiw, Lawrence H. Summers, and Richard J. Zeckhauser. 1989. Assessing dynamic efficiency: Theory and evidence. The Review of Economic Studies 56(1): 1-19.

Abiad, Abdul, Enrica Detragiache, and Thierry Tressel. 2008. A new database of financial reforms. IMF Working Paper, 08/266.

Aguiar, Mark, and Gita Gopinath. 2007. Emerging market business cycles: The cycle is the trend. Journal of political Economy 115(1): 69-102.

Arellano, Cristina. 2008. Default risk and income fluctuations in emerging economies. American Economic Review 98(3): 690-712. 
Asonuma, Tamon, and Christoph Trebesch. 2016. Sovereign debt restructurings: Preemptive or postdefault. Journal of the European Economic Association 14(1): 175-214.

Bai, Jushan, and Pierre Perron. 1998. Estimating and testing linear models with multiple structural changes. Econometrica 66: 47-78.

Ball, Laurence, Douglas W Elmendorf, and N Gregory Mankiw. 1995. The deficit gamble. Cambridge: National Bureau of Economic Research.

Barrett, Philip. 2018. Interest-growth differentials and debt limits in advanced economies. IMF Working Paper, 08/266.

Best, Tom, Oliver Bush, Luc Eyraud, and M. Belen Sbrancia. 2019. Reducing debt short of default. In Sovereign Debt: A guide for economists and practitioners, ed. Ali Abbas, Alex Pienkowski, and Kenneth Rogoff. Oxford: Oxford University Press.

Blanchard, Olivier. 2019. Public debt and low interest rates. American Economic Review 109(4): 1197-1229.

Bohn, Henning. 2008. The sustainability of fiscal policy in the United States. In Sustainability of Public Debt, ed. Reinhard Neck, and Jan-Egbert Sturm. Cambridge, MA: MIT Press.

Broner, Fernando A., Guido Lorenzoni, and Sergio L. Schmukler. 2013. Why do emerging economies borrow short term? Journal of the European Economic Association 11(1): 67-100.

Chari, V V, Alessandro Dovis, and Patrick J Kehoe. 2020. On the optimality of financial repression. Journal of Political Economy 128(2):710-739.

Cottarelli, Carlo, Paolo Mauro, Lorenzo Forni, and Jan Gottschalk. 2010. Default in Today's Advanced Economies: Unnecessary, Undesirable, and Unlikely. IMF, Staff Position Note, 10/12.

Detragiache, Enrica, and Antonio Spilimbergo. 2001. Crises and liquidity: Evidence and interpretation. IMF Working Paper, 01/2.

Eichengreen, Barry, Ricardo Hausmann, and Ugo Panizza. 2010. The pain of original sin. In Other People's, and Money: Debt Denomination and Financial Instability in Emerging Market Economies, ed. Barry Eichengreen, and Ricardo Hausmann. Chicago: University of Chicago Press.

Escolano, Julio. 2010. A practical guide to Public Debt Dynamics, fiscal sustainability, and cyclical adjustment of budgetary aggregates. IMF Technical Notes and Manuals, 10/02.

Escolano, Julio, Anna Shabunina, and Jaejoon Woo. 2017. The puzzle of persistently negative interestrate-growth differentials: Financial repression or income catch-up? Fiscal Studies 38(2): 179-217.

Garín, Julio, Robert Lester, Eric Sims, and Jonathan Wolff. 2019. Without looking closer, it may seem cheap: Low interest rates and government borrowing. Economics Letters 180: 28-32.

Geerolf, François. 2018. Reassessing dynamic efficiency. Los Angeles: University of California at Los Angeles.

Giovannini, Alberto, and Martha De Melo. 1991. Government revenue from financial repression. National Bureau of Economic Research.

Girouard, Nathalie, and Christophe André. 2005. Measuring cyclically-adjusted budget balances for OECD countries. OECD Economics Department Working Papers.

Gourinchas, Pierre-Olivier, and Maurice Obstfeld. 2012. Stories of the twentieth century for the twentyfirst. American Economic Journal: Macroeconomics 4(1): 226-65.

International Monetary Fund. 2020. Global Financial Stability Report.

Jeanne, Olivier, and Anastasia Guscina. 2006. Government debt in emerging market countries: A new data set. IMF Working Paper, 06/98.

Jordà, Òscar, Katharina Knoll, Dmitry Kuvshinov, Moritz Schularick, and Alan M. Taylor. 2019. The rate of return on everything, 1870-2015. The Quarterly Journal of Economics 134(3): 1225-1298.

Jordà, Òscar, Moritz Schularick, and Alan M. Taylor. 2017. Macrofinancial history and the new business cycle facts. NBER Macroeconomics Annual 31(1): 213-263.

Kozlowski, Julian, Laura Veldkamp, and Venky Venkateswaran. 2019. The tail that keeps the riskless rate low. NBER Macroeconomics Annual 33(1): 253-283.

Mauro, Paolo, Nathan Sussman, and Yishay Yafeh. 2002. Emerging market spreads: Then versus now. The Quarterly Journal of Economics 117(2): 695-733.

Mauro, Paolo, Nathan Sussman, and Yishay Yafeh. 2006. Emerging markets and financial globalization: Sovereign bond spreads in 1870-1913 and today. Oxford: Oxford University Press.

Mauro, Paolo, Rafael Romeu, Ariel Binder, and Asad Zaman. 2015. A modern history of fiscal prudence and profligacy. Journal of Monetary Economics 76: 55-70.

McCallum, Bennett T. 1976. Rational expectations and the estimation of econometric models: An alternative procedure. International Economic Review 17: 484-490. 
Mehrotra, Neil. 2019. Implications of low productivity growth for debt sustainability. In Adam Posen and Jeromin Zettelmeyer, ed. Facing up, and to low productivity growth. Washington, DC: Peterson Institute for International Economics.

Mehrotra, Neil R, and D Sergeyev. 2020. Debt sustainability in a low interest rate world. CEPR Discussion Paper No. DP15282.

Moreno Badia, Marialuz, Paulo Medas, Pranav Gupta, and Yuan Xiang. 2020. Debt Is Not Free. IMF Working Paper, 20/1.

Morsy, Hanan, Ludvig Söderling, Martin Petri, Manal Fouad, and Wojciech Maliszewski. 2007. Public debt and fiscal vulnerability in the Middle East. International Monetary Fund.

Obstfeld, Maurice, and Alan M. Taylor. 2005. Global capital markets: Integration, crisis, and growth. Cambridge: Cambridge University Press.

Piketty, Thomas. 2014. Capital in the twenty-first century. Cambridge, MA: Harvard University Press.

Rachel, Łukasz, and Lawrence H. Summers. 2019. On secular stagnation in the industrialized world. Cambridge: National Bureau of Economic Research.

Reinhart, Carmen M., and Kenneth S. Rogoff. 2009. This time is different: Eight centuries of financial folly. Princeton: Princeton University Press.

Reinhart, Carmen M., and M. Belen Sbrancia. 2015. The liquidation of government debt. Economic Policy 30(82): 291-333.

Reinhart, Carmen M., Jacob F. Kirkegaard, and M. Belen Sbrancia. 2011. Financial repression redux. Finance and Development 48: 22-26.

Schmelzing, Paul. 2019. Eight centuries of global real interest rates, R-G, and the 'suprasecular' decline, 1311-2018. Bank of England Staff Working Paper No. 845.

Turner, David, and Francesca Spinelli. 2011. Explaining the interest-rate-growth differential underlying government debt dynamics. OECD Economics Department Working Papers.

Publisher's Note Springer Nature remains neutral with regard to jurisdictional claims in published maps and institutional affiliations. 